\title{
New Actors and Innovative Approaches to Peacebuilding: The Case of Myanmar
}

\author{
Lina A. Alexandra and Marc Lanteigne
}

We would like to show our appreciation due to the extensive support given by different institutions both in Myanmar and Indonesia which contribute to the conclusion of this report. In Myanmar, we would like to thank the Embassies of Indonesia, especially Dr. Ito Sumardi (Indonesian Ambassador to Myanmar 2013-2016), India, Japan, Norway, Switzerland to Myanmar; officials in the Strategic Studies and Training Department of the Ministry of Foreign Affairs (MOFA) Myanmar, Myanmar Human Rights Commission, and representatives of the Myanmar Armed Forces (Tatmadaw) and the commissioners from the Myanmar National Election Commission on the subject of pre- and post-election security in the country.; academics and researchers in the Yangon University, the Myanmar Development Research Institute (MDRI) /Center for Strategic and International Studies (CSIS), Myanmar Institute of Strategic and International Studies; the Mingalar Myanmar and the Shalom (Nyein) Foundation. We would like to thank also senior-level officials from the Indonesian Ministry of Foreign Affairs, especially Dr. Hassan Wirajuda (2001-2009); the Institute for Peace and Democracy (IPD); the former Indonesian Ambassador to Myanmar, Dr. Sebastianus Sumarsono (2008-2013); the Indonesian National Election Commission; Indonesian parliament member (Commission I); and The Habibie Center.

\section{L.A. Alexandra $(\bowtie)$}

Centre for Strategic and International Studies (CSIS), Jakarta, Indonesia

M. Lanteigne

Centre for Defence and Security Studies, Massey University, Auckland, New Zealand

(C) The Author(s) 2017

C.T. Call, C. de Coning (eds.), Rising Powers and

Peacebuilding, Rethinking Peace and Conflict Studies, DOI 10.1007/978-3-319-60621-7_9 


\section{INTRODUCTION}

The positive movement towards political and economic reformation in Myanmar, (also known as Burma), began in the wake of reform processes since 2010 to the current administration under President Thein Sein, and has attracted the attention of various international actors interested in assisting the Myanmar government, economically and politically. Central to this attention has been the ongoing peacebuilding process in Myanmar, specifically the potential war-to-peace transition in the country as ceasefires and other political agreements between the Myanmar government and armed opposition forces are crafted. Both traditional partners as well as new actors in Myanmar diplomacy have developed policies and have approached the country's government to gather more information about how they could contribute positively to building sustainable peace in the country. This question became more pressing during the period leading up to the state elections on 8 November 2015. This vote, while not perfect, was the most inclusive in the country in decades, and was seen as a barometer on the overall reform process as well as ongoing attempts to develop a peace plan for the periphery of the country. The landslide win by the National League for Democracy (NLD), headed by former dissident Aung San Suu Kyi, promised to jump start many needed reforms in the country. Although the military-backed constitution prevented Ms. Suu Kyi from assuming the position of president, she currently serves as 'State Councillor', a position akin to that of a prime minister, and also holds the positions of Foreign Minister and Minister of the Office of the President. Her colleague within the NLD. Mr Htin Kyaw, assumed office in March 2016. After her first year in office, she acknowledged that much more work needed to be down in the areas of governmental reform, economic development and peacebuilding, and in March 2017 suggested that she would be in a position to step down if the public was dissatisfied with her performance.

When speaking of the 'reform' processes in Myanmar at present, one can identify four separate streams which can be differentiated but are nonetheless very closely tied together as this report will examine:

1. A transition from military rule to an intermediate 'mixed' system of civilian-military governance, with the promise of a return to full civilian administration and democratic institutions in the near term.

2. The end of civil conflicts in the periphery of Myanmar as governmental and opposition forces agree to a cease-fire and a peaceful 
resolution to political disputes which have plagued the country for over five decades.

3. The conversion of the Myanmar economy from a command system to a liberalising one, developing stronger trade ties and private business development. This is key to alleviating the ongoing problem of widespread poverty, which is viewed not only as a socio-economic crisis but also a security threat.

4. The expansion and diversification of Myanmar's diplomatic contacts not only with other Asian governments, (including ASEAN), but also with major international actors including Western Europe and the United States.

This study of new actors in peacebuilding focuses on the role of external players in the second of these four processes, but mindful of how that process relates to the other three vital areas of reform that Myanmar has been undertaking. The study focuses especially on two countries which have played differing but prominent roles in peacebuilding, namely China and Indonesia. These countries represent three distinct types of actors in terms of their engagement in the country. Indonesia represents an emerging actor in Myanmar's diplomacy, both as a single player as well as a prominent member of ASEAN. Indonesia is still often categorised as a developing country but for the last decade or so has been viewed as an emerging market and as a stabilising force in Southeast Asian security. Jakarta has been seeking to develop its peacebuilding policies in recent years, with Myanmar being as a key case study. Bilateral relations were established during the early period of Indonesia's independence in January 1948, and solidified after Myanmar joined ASEAN in 1997, a move supported by most governments in the region, including Indonesia.

On the other hand, China represents another new actor in peacebuilding arena with different characteristics. In some ways, calling China a 'new' actor in Myanmar peacebuilding is a mis-categorisation, given that the two neighbouring countries have had longstanding diplomatic and economic contacts since the independence of Burma, and Beijing was one of the few regional governments to maintain ties with Myanmar during that country's period of diplomatic isolation between the late 1980s and 2010. However, in recent years China has been seeking to improve its identity in Myanmar through various diplomatic initiatives, due to public concerns about both its dominant role in the Myanmar economy as well as its previous good relations with the pre-reform military governments (SLORC and its successor, the SPDC). 
Since 2014, there have been disputes across the Sino-Myanmar border, as well as signs of a cooling in political relations between the two states. Beijing nonetheless continues to see Myanmar as a vital partner both in energy trade as well as the ambitious plans of President Xi Jinping to develop port facilities in the Indian Ocean as part of China's 'Belt and Road' regional development initiatives first introduced by the Xi Jinping government in 2013. Beijing is wary of the possibility of enhanced Western engagement in Myanmar, seeing warming relations with the United States as especially difficult given the current strategic 'rebalancing' policy in Asia announced by the Obama administration in 2011 which many policymakers in China have perceived as tacit containment of Chinese power.

As a response, Beijing has been seeking to develop greater soft power in Myanmar in the face of developing diplomatic and trade competition from the West, especially the United States, Western Europe, and Australia, but also from Japan, India and other governments in Asia. Although it is likely that the next government in Myanmar will continue to diversify the country's foreign policy and possibly return to a more non-aligned strategic identity which was the norm before the end of the 1980s, Beijing by necessity will continue to be a major part of Myanmar's regional relations given China's status as a rising power and due to geographic realities.

This project seeks to compare the approaches to peacebuilding undertaken by these three external actors to gauge their policies as well as measure their successes on different levels in the transition period leading up to the November 2015 elections and beyond. After the analyses of these case studies, it will useful to briefly analyse comparative cases of other distinct peacebuilding actors in Myanmar, namely Norway as well as India, Japan and Switzerland, to provide further information regarding similarities and differences in approaches to peacebuilding concepts and practices. These four external actors for reasons of economy, focus and parsimony, but there are of course many other examples of foreign actors which have also begun to engage Myanmar, both economically and politically.

The two main cases of China and Indonesia are perceived as new (or emerging) actors, although arguably neither term is wholly accurate, whereas Norway and Switzerland are more 'traditional' Western donors. Japan can be seen as a 'returning' actor given that Tokyo's diplomatic and economic presence in what was then Burma was very strong until the 1980s, and India is certainly not a stranger to Myanmar politics, but has been at best a minor actor in peacebuilding but is seeking to take 
advantage of the developing reforms to better improve its position, both on a unilateral basis as well as due to concerns about Beijing's growing strategic presence in the Indian Ocean.

\section{INDONESIA's ENGAGEMENT IN MYANMAR}

\section{Rationales and Strategic Objectives}

While Indonesia's engagement in Myanmar's transition, particularly in the area of peacebuilding, can be viewed as relatively recent, the foundation of the relationship between the two countries goes back more than half a century. Burma was listed as one of the first countries to recognise Indonesia's struggle for independence, and the two governments appreciated each other's independence struggles with European colonial powers. In 1947, only two years after Indonesia's founding fathers President Soekarno and Vice-President Mohammad Hatta declared the country's independence from colonial powers, the Burmese government gave permission to open an Indonesian Office in Rangoon (now Yangon). The Burmese leaders at that time even addressed the Indonesian diplomats as representatives of the Republic of Indonesia in front of the Dutch authorities who at that time refused to acknowledge Indonesia's independence.

During those difficult times, in 1949 the Burmese government accepted the request of the Indonesian government to allow for Indonesian Dakota RI-001 aircraft to land in Mingladon Airport, Rangoon and later helped to set up the first commercial Indonesian Airways in Burma. Furthermore, the Prime Minister of Burma, $\mathrm{U}$ Nu, together with Indian Prime Minister Jawaharlal Nehru, continued to rally support for Indonesia's struggle against its former colonial power by organising the Conference on Indonesia in New Delhi to condemn military activities conducted by the Dutch (Indonesia Embassy 2001).

Bilateral relations were very much watered down during Myanmar's isolationist period. Myanmar under the socialist system, which led to later economic traumas, created even less incentive for ASEAN countries, including Indonesia, to revoke its relations with the country. Hopes that Myanmar would be in a position to join ASEAN were dashed in the wake of the uprising which broke out in August 1988, followed by the consolidation of military rule in the country and the annulment of the results of the 1990s elections. ASEAN as the only regional organisation in the area, 
was heavily pressured to respond to the situation. Even after Myanmar joined ASEAN, relations between the country and other members were brittle, especially in the wake of the 2007 'Saffron Revolution' and the government's mishandling of aid after Cyclone Nargis in May 2008.

Compared with China, Indonesia has fewer geopolitical and geoeconomic interests in Myanmar. Indonesia shares no border with Myanmar, and strengthening bilateral economic ties has been a struggle especially due to the low interest from the Indonesia's business sectors in venturing into Myanmar's still-emerging market. One of the results from the Second Joint Commission for Bilateral Cooperation (JCBC) between Indonesia and Myanmar in late December 2011, the two leaders committed to increase the trade volume to US $\$ 500$ million by 2015 (Zaw 2012). Then around one year later, during the third meeting of the JCBC, as a follow-up to President Yudhoyono's state visit to Naypyitaw in April 2013, the two countries raised the expectation to achieve US\$1 billion trade value by 2016 (Winarti 2013). Nevertheless, there are several means to explain Indonesia's motivations to engage with Myanmar. The first is at the domestic level. Based on the elaborations above, a long-term relationship which was established since the early period of Indonesia's independence between the two countries has created a solid basis for the Indonesian government throughout the history to develop ties with Myanmar. Due to generous pre-independence support given by Myanmar in the past, Indonesian policymakers have an implicit 'indebted' feeling, which has obliged the country to return the favour to Myanmar.

The second domestic factor is a combination of Indonesia's internal need and ambition to spread its newly adopted value-democracy-in the region in order to create an improved environment for its own democracy to grow at home. In the wake of the 1998 protests and the first direct presidential elections in 2004 which brought to power Susilo Bambang Yudhoyono, Indonesia managed to overcome its internal political and economic challenges to install a civilian government after thirty-two years of semi-authoritarian government during the New Order era (1965-1998), and embrace democracy as its new identity. Besides implementing various policies at the domestic level to deepen its democratic project-direct elections, autonomy, security sector reform, and so on, interestingly Indonesia has been also aiming high to project its democracy abroad, in order to create a supporting environment for its own democracy to grow to the fullest. As elucidated by former Foreign Minister Hassan Wirajuda, '[S] ince a democracy works best in a democratic environment, we should also 
like to see the further growth of democratic values in our own neighbourhood.' (Wirajuda 2005).

Myanmar has become a focus for Indonesia to project its democracy for various reasons. Other than historical debts, more importantly because the two countries see some similarities between them. Indonesia was once under the rule of General Soeharto during the 32 years of New Order era, which is very much the situation Myanmar is currently in. During the era of President Yudhoyono, who was a retired general, Indonesia enjoyed special relationships compared to other countries which allowed its engagement with Myanmar to flourish, even allowing for some dialogue on sensitive issues such as the ongoing Rohingya question. One of the reasons, as mentioned by an Indonesian foreign ministry official is simply because the Myanmar government is comfortable working with a government which has a history of 'military thinking', and still has military issues to resolve in politics (Macan-Markar 2013). This is particularly true as both countries are facing challenges of ethnic conflicts as well as separatism in their territories. Both governments are also facing gaps in the relations between the majority and minority groups, notably along the religious lines-Indonesia is majority Muslim while Myanmar has a Buddhist majority. Therefore, at least from these aspects, there are some modalities to tap on for Indonesia to projecting its democracy.

Regional factors have also shaped Indonesia's recent policies. Myanmar's location in the Southeast Asian region, and also its proximity to China and India, means that whatever happens in Myanmar immediately comes to the attention of countries in the region and of ASEAN itself. Indonesia's interest in engagement is further fuelled by its more consistently defining itself as a natural leader in the region and in ASEAN, which Myanmar officially joined in 1996. Indonesia has more or less shared the same interests with other ASEAN member countries' founding members on the need to embrace the Indochina countries and bring them into ASEAN, particularly in the case of Myanmar, which the organisation granted observer status to in 1991. The biggest interest of ASEAN at that time was to restrain increasing Chinese influence in the region which was seen as breaking Myanmar's traditional neutralism and transforming the country into China's 'satellite' in the region as well as creating an entry point for Beijing to better influence Southeast Asia, given China's long border with Myanmar and the latter country's placement on the Indian Ocean (Weatherbee 2009), which has emerged as an essential maritime trade route for Beijing as it enhances its trade with Africa and the Middle East. 
Moreover, ASEAN's founding members, including Indonesia, ${ }^{1}$ viewed engagement with Myanmar as crucial to close the loophole for major powers, especially Western countries, to intervene unilaterally in the region. Due to severe criticism from those outside powers, particularly the United States, over Myanmar's human rights violations, there has been a very strong interest from ASEAN countries for Southeast Asia to become an autonomous regional order where the members become masters of their own region, as indicated in Indonesia's initiatives back in 1971, and even now in the post-2015 agenda, to establish the 'Zone of Peace, Freedom and Neutrality' (ZOPFAN) in ASEAN (Anwar 2005). Relations between Myanmar and other ASEAN members, especially Thailand, remain problematic in some areas, but since the reform process in Myanmar began five years ago more doors have been opened for a deepening of the MyanmarASEAN relationship.

\section{Types of Engagement}

Generally, Indonesia's engagements with Myanmar have been established in most sectors, especially in political, economic, development, and military ones. Compared to other actors in the region, such as Singapore, Thailand and China, Indonesia can be considered as relatively newcomer in term of its economic engagement with the country. It can be said that Indonesia has within the past few years begun to reap some economic benefits from the country's carefully tended engagement with the military regime in Myanmar.

In 2014, total exports from Indonesia to Myanmar reached US\$566 million in value which dominated by non-oil commodities, such as palm oil, cigarettes, clothing (sarong), and traditional medicines. Alternatively, Indonesia's imports from Myanmar rose significantly from US\$73 million in 2013 to US\$122 million in 2014, and dominated by non-oil commodities such as beans, especially mung beans and soybeans and also seafood products (Kompas 2009). In 2015, the Indonesian government was exploring the establishment of direct banking connections and to allow more flight connections between the two countries (Garuda Indonesia 2015). Then, to boost investments in Myanmar, current Indonesian President Joko Widodo, during the ASEAN Summit in Naypyidaw in 2014, announced plans to augment Indonesia's investments in Myanmar in three sectors: mining, telecommunications and infrastructure (Dunia 2014). 


\section{Non-Political Engagements}

There are several sectors in the Myanmar economy which Indonesian companies have just recently become involved in within the past five years, including construction, telecommunication, and banking. Some leading construction companies such as Ciputra Group, Lippo Group, and Wijaya Karya (WIKA) have shown interest in taking advantage of almost $15 \%$ increase within the period of 2009-2013 in Myanmar's construction needs. WIKA has undertaken a US\$270 million multifunctional development project in Yangon, involving commercial and residential units to be accomplished in 2017. Lippo Group, on the other hand, has been planning to invest US\$1 billion to building 20 hospitals over the next three to five years and also aimed to seek opportunities in retail sector (Firdaus 2015; Antara News 2015). In 2013, the Indonesian state-owned telecommunication company Telkom won the tender to participate in modernising the information and communication technology in the country (Telkom 2013). Later on, in banking sector, the Indonesian state-owned bank, Bank Negara Indonesia (BNI) just built its first representative office in Yangon in November 2014 (Sipahutar 2014).

In the development area, Myanmar has been regarded as one of key partners to be engaged under Indonesia's framework of South-South and Triangular Cooperation (SSTC) of Indonesia. As a result of the second Joint Commission on Bilateral Cooperation (JCBC) between Indonesia and Myanmar, as recorded in the Blue Book on Indonesia-Myanmar Capacity Building Partnership, Indonesia has committed itself to providing assistance in the form of training and seminars/workshops as well as experts in the area of small and medium enterprises (SMEs), microfinance, national reconciliation, agriculture, local governance and media during the period of 2013-2015 (Ministry of Foreign Affairs 2015). The Indonesian government, through its state-owned electricity company, also committed itself to providing technical consultation assistance to help Myanmar to address its national electricity losses which reached up to $26 \%$ (Xinhua 2013). Besides this regular assistance, Indonesia has also helped Myanmar during emergency situations including the aftermath of Cyclone Nargis in 2008. ${ }^{2}$ Jakarta also donated US\$1 million to the Tripartite Core Group, composed of three members from the Myanmar government, three members from ASEAN and three representatives from the United Nations, for the victims of Cyclone Nargis (Shin 2009).

In terms of military engagement, there are limited interactions, there have been limited interactions, including regular military training courses 
and particularly on medical courses provided by the Indonesian armed forces so far. For the past two years, the Indonesian military has engaged in sharing specific knowledge and experiences on the role of the military in a democratic state. As of now, there are three military officers in Indonesia attending courses in the National Defence Institute (Lembanas/Lembaga Ketahanan Nasional) in Myanmar. ${ }^{3}$ Recently, there has been interest from the Myanmar government to purchase various defence products produced by Indonesian companies to enhance the capabilities of Myanmar's military and police (Tempo 2014).

\section{Political Engagement}

In addition to these economic and development engagements, Jakarta has been focusing further in its political engagements with Myanmar. However, this initiative, rather then being placed in a bilateral framework, was instead framed in a regional setting, especially through Indonesia's aspiration to nurture its leadership role in ASEAN. The country has tried to regain its central role within ASEAN as soon as it was relatively able to cope with its internal struggles between 1998 and 2002. When Jakarta chaired ASEAN in 2003, it came up with a very aggressive proposal of creating ASEAN Security Community (ASC)—which later modified into ASEAN Political Security Community (APSC).

The most critical ideas brought forward by Indonesia within ASEAN at that time was to insert the new principles of democracy, good governance and rule of law, as well as the promotion and protection of human rights as ASEAN's shared norms and values-points which were unthinkable or even an anathema for ASEAN to mention in the past, since some member countries are still categorised as 'non-democratic' or 'semi-authoritarian' states. Within this context, Indonesia has played an active role in persuading the non-democratic member countries of ASEAN toward observing these new ASEAN's common values and norms-which then later even brought higher by creating the Bali Democracy Forum (BDF) movement in 2008, with a mission to convert ASEAN countries into more robust democracies.

Indonesia's political engagements-after Indonesia's reformation erawith Myanmar started in 2003 when the Indonesian foreign minister Ali Alatas, a very capable diplomat, visited the country, after he was appointed as the United Nations special envoy to Myanmar. From the outset, no major breakthrough seemed to take place since the military junta continued to run the Myanma political affairs as usual. Even four years later, in 
2007, when President Yudhoyono sent a retired reformist general, Agus Widjojo, to Myanmar, officially to attend the funeral of former Prime Minister Soe Win, but with a mission to convince the military junta to start thinking about political reform following the brutal military crackdown of anti-government protests led by Buddhist monks, nothing can be claimed as a significant result. The Indonesian president could not even get a guarantee that his plan to visit the country would bring some significant outcome, which then made him eventually postpone his visit indefinitely simply not to lose face. The momentum then arrived for Indonesia to again reassert its role, this time in a deeper fashion, after Cyclone Nargis.

Immediately after the disaster laid waste to much of Myanmar, the military junta shut down access for humanitarian aid to enter the country and help the victims, despite the authorities' lack of capabilities to provide such emergency relief. Indonesia's then-foreign minister, Hassan Wirajuda, known for pushing ASEAN to embrace new principles of democracy and human rights, took the initiative to place ASEAN at the forefront, since entreaties from many Western governments to persuade the junta to allow emergency ingress into Myanmar came to no avail. Aside from Indonesia's humanitarian assistance to send capable experts involved in dealing with Indian Ocean tsunami disaster in Aceh back in 2004, more importantly Jakarta played an instrumental role to persuade the military junta, with some pressure, to reconsider its restrictions on foreign disaster assistance. The foreign minister, in one meeting, basically offered the Myanmar government two options. First, it can allow an ASEAN-led mechanism to help coordinating the whole humanitarian assistance that were coming in to the country. Second, the junta could simply do nothing but would have to explain what was the meaning of Myanmar joining ASEAN in the first place. As a result, ASEAN then was given the role of aid coordination as the Myanmar belatedly opened up access for humanitarian assistance to flow into the country.

It is important to note that rather than being a one-way effort, Indonesia's overall engagement with Myanmar was made possible due to Myanmar's developing interests towards Indonesia's political processes from the very beginning. Under the New Order era, led by President Soeharto, a Burmese delegation at that time led by the then-Chief of Intelligence Unit Lieutenant General Khin Nyunt visited Indonesia in December 1993 to study the Indonesian military's 'dual function', defence and politics, system. Such interest has still been expressed today, since such a system has been perceived by many stakeholders in Myanmar as 
providing a gradual and stable transition from military into full civilian-led government in later years. Furthermore, many stakeholders in Myanmar also expressed interest in learning about Pancasila, the formal philosophical foundations of the State of Indonesia, particularly the idea of Bhinneka Tunggal Ika ('Unity in Diversity'), the official maxim of Indonesia, since the two countries have shared almost similar challenges with ethnic diversity and associated periodic political tensions.

While there has been some internal criticisms of the Indonesia government to be late when it comes to reaping the benefits of its early political investments in Myanmar, to some extent there is an interesting finding that such 'unfortunate' situation has somehow situated Indonesia in a better position compared to other actors, such as China, India and Japan, which have expanded their economic interests in the country (Chachavalpongpun 2010). Indonesia has been able to secure more trust to play a role of peace-builder, which will be elucidated in the next section, due to its relatively low-key presence in terms of business or economic activities in Myanmar so far.

\section{Role in Peacebuilding/Peace-Related Areas}

Indonesia's governmental role in peacebuilding in Myanmar is unique, in the sense that it has been directed more towards larger and more highlevel contexts, including projecting democracy as the basic foundation to create sustainable peace. Here, Jakarta has been focusing itself to share its experiences in democratic transitions, including on how to manage with the 'messy' side effects of such processes. What makes it different is the emphasis on the usage of 'democratic' methods that are different from what the traditional actors, mainly Western countries, used to apply.

It is certainly not an easy task to grasp how the Indonesia policymakers define the term peacebuilding. When directly asked about their understanding on the term, most of them relate it with the UN definition, in which peacebuilding is a set of activities conducted after peace has been relatively achieved through the sigining of peace agreement between the conflicting parties. Within this context, then, some argued that peacebuilding itself is relatively a new experience for Indonesia and the country has just started to learn the process during the Aceh peace process which taken place after the Tsunami disaster severely hit the province in the end of 2004 . As stated by one general, "Peacebuilding is also something new for Indonesia. We learn it in the case of Aceh. There is no template, we just 
follow the needs of the ground." 4 This argument has been confirmed by Indonesia's former Minister of Foreign Affairs, as he went on to describe how the Indonesian government at that time involved in the process to bring former combatants from Free Aceh Movement (Gerakan Aceh Merdeka) group members to enter into normal civilian life, including to regulate the distribution of lands and establishment of local government. ${ }^{5}$

Then, when asked whether Indonesia's roles in Myanmar can be categorised as peacebuilding efforts, most of them were not too sure. This is reflected from the comment given by the former Indonesian Ambassador to Myanmar (2008-2013), Sebastianus Sumarsono, when being interviewed regarding Indonesia's active role in the country:

I am not sure whether those things are part of peacebuilding ... Not only in peacebuilding, but in many aspects of life we participate in helping Myanmar.

Such a view was also confirmed by Minister Wirajuda as he argued that it is hard to say that peacebuilding has taken place in Myanmar since peacemaking has not taken place in the country. ${ }^{6}$

\section{Principles}

There are several principles upheld by the Indonesian government to indicate democratic ideas in its engagement with Myanmar. The first, and the most important, is sharing. Fully aware of differences between the two countries, the idea behind this sharing is to provide Myanmar, once an isolationist state, with real evidence that transition into a democratic civilian-led government is not an impossible idea, as demonstrated in the Indonesian case. It is always debatable whether Indonesia's past experience, with its dual-function military and semi-authoritarian regime, is a good example to present. However, one argues that at least the Indonesian case presents an alternative to the Myanmar's leaders for the country to follow in walking the path of limited democratic reform and economic development (Renshaw 2013). Based on interviews with several Indonesian stakeholders, the 'sharing' activities conducted so far are aimed not only to share best practices, but also more importantly discuss Indonesia's mistakes of the past, which should not to be repeated in Myanmar. Moreover, by elucidating the concept of 'sharing', Indonesia positions itself not as being superior to its Myanmar counterpart, with the former dictating to the latter, but rather as a partner on equal footing. 
The second principle, which is the consequence of the 'sharing' approach, is to work at the pace that is comfortable for all, especially the partner country, while giving some pressures when necessary. For the engagement to achieve success, Indonesia believes that it is important spend more energy and time to build confidence and trust, especially with the government, and wait until the initiative for change comes from the local stakeholders in order to grow the sense of ownership of the reform process. According to one director in MoFA, the approach should be based 'on their request, not ours because it involves changing of the culture and mindset of the society [regarding the democracy promotion]' ? Such an approach often been criticised not only by Western countries, but also by some segments of Indonesian society, as being too accommodative, powerless, or even ineffective. However, the Indonesian government particularly believes that it is very crucial not to give an impression of seeking to impose a worldview on others, as it may create counterproductive results. Former Minister Hassan Wirajuda when confronted with this criticism, made an interesting argument as he described Indonesia's approach to Myanmar when it persuaded the military junta to receive an ASEAN-led humanitarian assistance into the country in the aftermath of Cyclone Nargis disaster. According to him, Indonesia at that time actually made a straightforward movement by 'taking the bull by its horn' when the Indonesian government challenged the regime in Myanmar to consider the meaning of its participation in ASEAN should the ASEANled proposal also being rejected. While he strongly disagree with sanction mechanism to 'punish' Myanmar, as implemented by many Western countries, Wirajuda argued that there is no reason not to be able to apply what he called as 'constructive engagement' as shown from the case above. The spirit, according to him, should be like helping a family member in which 'rebuking' is justified to the extent that such action would bring better result than sanctioning. ${ }^{8}$

\section{Projects}

There are various projects related to peacebuilding efforts in Myanmar which have been implemented so far. The major theme for Indonesia's peacebuilding engagement in Myanmar is to sharing experiences in democratic transition on topics such as military reform, election processes, capacity building for parliament and political parties, and recently also managing ethnic relations, especially related to ethnic minority groups 
and questions of local autonomy/decentralisation. Those projects mainly took form in activities, such as visit, training, workshop, dialogue and so on which conducted by different agencies, starting from ministries, think tank institutions, local non-governmental organisations (NGOs) as well as international NGOs. The main implementing agency so far is the Indonesian Ministry of Foreign Affairs (MoFA), particularly the Directorate of Technical Cooperation which is responsible on all programmes within the framework of Indonesia's South-South and Triangular Cooperation (SSTC), including Indonesia's peacebuilding projects in Myanmar. Almost all of the projects, ${ }^{9}$ organised by government agencies as well as non-governmental institutions, were funded through a triangular framework, meaning that they received funding from the third parties.

One implementing institution, which is closely linked to the Indonesian MoFA, is the Institute for Peace and Democracy (IPD). The IPD, which is independent from the government in terms of its management and funding, was formed by the Indonesian Foreign Ministry, with the support of the state-run Udayana University. Its original primary function was to implement the Bali Democracy Forum (BDF)-Indonesia's ambitious intergovernmental forum to promote democracy by gathering countries which regard themselves as democratic to share their experiences to nondemocratic countries but have 'aspired to be more democratic'. The participants are from across the Asia-Pacific as well as the Middle East, and Myanmar is also a member. ${ }^{10}$

Recently, the organisation has been transformed into a fully independent institution which makes it no longer under the aegis of Udayana University. Specifically in Myanmar, IPD has organised different activities related to promotion of peace and democracy. Before designing certain programs/activities, the IPD first conducted the scoping mission in Myanmar to undertake needs assessment and scoping analyses, with the results being used to develop suitable programs and activities which would meet the expectations of different stakeholders in Myanmar. ${ }^{11}$ Based on consultations with the local stakeholders, the IPD implemented several activities in Myanmar, as illustrated in Table 9.1 below. Within those activities, most of the programmes were focused to provide capacity building in democracy and peace building, the role of media, parliament, political party, election, regional autonomy, ASEAN leadership, (especially when Myanmar was preparing to assume the ASEAN chair in 2014), a national human rights body, as well as administrative reform, development (agriculture) and economic decentralisation. 
Table 9.1 IPD's programs in Myanmar 2013-2014

\begin{tabular}{|c|c|c|c|}
\hline Program & Place & Date & Counterparts/beneficiaries \\
\hline $\begin{array}{l}\text { Indonesia-Myanmar } \\
\text { dialogue on democratic } \\
\text { transition: building } \\
\text { democracy and } \\
\text { sustainable peace }\end{array}$ & $\begin{array}{l}\text { Yangon, } \\
\text { Myanmar }\end{array}$ & $\begin{array}{l}26-28 \text { June } \\
2013\end{array}$ & $\begin{array}{l}\text { Myanmar MoFA, MISIS, MDRI } \\
\text { and other government officials }\end{array}$ \\
\hline $\begin{array}{l}\text { 2. Indonesia-Myanmar } \\
\text { dialogue on } \\
\text { decentralization, } \\
\text { democratization and } \\
\text { peace building }\end{array}$ & $\begin{array}{l}\text { Yangon, } \\
\text { Myanmar }\end{array}$ & $\begin{array}{l}24-25 \\
\text { September } \\
2013\end{array}$ & Myanmar MoFA, MISIS, MDRI \\
\hline $\begin{array}{l}\text { 3. Two-days dialogue on } \\
\text { leadership and political } \\
\text { party reform }\end{array}$ & $\begin{array}{l}\text { Denpasar, } \\
\text { Bali }\end{array}$ & $\begin{array}{l}9-10 \\
\text { November } \\
2013\end{array}$ & $\begin{array}{l}\text { Fifty delegates from various } \\
\text { institution in Myanmar, i.e. } \\
\text { political parties, parliament } \\
\text { members, MISIS, MDRI, } \\
\text { Myanmar Peace Centre, Union } \\
\text { Solidarity and Development } \\
\text { Party (USDP), National League } \\
\text { for Democracy (NLD), media } \\
\text { and non-government } \\
\text { organisations }\end{array}$ \\
\hline $\begin{array}{l}\text { 4. Indonesia-Myanmar } \\
\text { dialogue on parliamentary } \\
\text { building } 2014\end{array}$ & Bali & $\begin{array}{l}7-9 \text { April } \\
2014\end{array}$ & $\begin{array}{l}\text { Attended by } 25 \text { participants } \\
\text { from Myanmar }\end{array}$ \\
\hline $\begin{array}{l}\text { Election visit program } \\
\text { to the indonesian } \\
\text { presidential election } 2014 \\
\text { and workshop for the } \\
\text { Indonesian presidential } \\
\text { election }\end{array}$ & $\begin{array}{l}\text { Jakarta, } \\
\text { Indonesia }\end{array}$ & $\begin{array}{l}8-10 \text { July } \\
2014\end{array}$ & $\begin{array}{l}\text { MDRI, Myanmar Center for } \\
\text { Strategic and International } \\
\text { Studies }\end{array}$ \\
\hline $\begin{array}{l}\text { Workshop on sharing } \\
\text { experiences on } \\
\text { development institutions: } \\
\text { can decentralization bring } \\
\text { peace, democracy and } \\
\text { local development? }\end{array}$ & $\begin{array}{l}\text { Yangon, } \\
\text { Myanmar }\end{array}$ & $\begin{array}{l}17-18 \\
\text { March } \\
2015\end{array}$ & $\begin{array}{l}\text { Myanmar MoFA, MISIS } \\
\text { Academics, policy makers and } \\
\text { government officials from } \\
\text { Myanmar, Lao, and Vietnam }\end{array}$ \\
\hline
\end{tabular}

Sources: IPD's website, and information from the Directorate of Technical Cooperation, Ministry of Foreign Affairs

On the subject of elections, Indonesia has carried out different programmes, such as capacity-building in election monitoring and security maintenance, during the Myanmar electoral process. Here, it is interesting to note that while few projects were initiated and coordinated by the 
Indonesian government, some others were actually initiated and carried out by non-governmental organisations (NGOs), including international NGOs, while Indonesian cases have been selected as references for Myanmar to take the lessons from. Here, we can see some useful collaborations existing between traditional Western donors with Indonesian partners who have the knowledge and experiences to better engage with Myanmar under reform.

For example, during the Myanmar election in 2010, the Indonesian embassy in Yangon sent a team to five different regions in Myanmar as observers. ${ }^{12}$ Toward the upcoming national election in November 2015, Indonesia through the cooperation with different agencies has also been engaging to provide its support. As reported by local media, Indonesia has managed to provide some consultations to the Myanmar police in their preparation for election security requirements (Htoo 2015). Regarding the technicalities of election preparation, recently the Asia Foundation sponsored a tour for a delegation from Myanmar's Union Election Commission (UEC) to visit Indonesia which included a meeting with the chair and commissioners of the Indonesian National Election Commission, the local election commission in Yogyakarta, as well as non-governmental organisations, such as Perludem, (the Indonesian Association for Elections and Democracy), Google's Jakarta office on how it engaged Indonesia's voters and provided access to 2014 elections information using online services, the Institute for Inclusion and Advocacy of Persons with Disabilities (SIGAB), and Solidaritas Perempuan which particularly focuses its advocacy work for women's rights in Indonesia (Lee and Myint 2015).

Moreover, in the area of law enforcement, the Indonesian government in cooperation with the Myanmar government and the British government organised an International Training on the Strengthening of Law Enforcement in Jakarta on 4-13 June 2015. The training was implemented by Police Educational Institution, (Lembaga Pendidikan Polisi Republik Indonesia/Lemdikpol), and attended by twenty-five members of Myanmar Police force. According to the press release, such training was particularly designed to enhance the capacities of the local police in maintaining safe environment in the upcoming election in November 2015. The Indonesian National Police has been specifically selected due to its previous experiences to provide similar capacity-building for Timor-Leste in 2013 and Afghanistan in 2014 (Ministry of Foreign Affairs 2015).

Another noteworthy project was recently organised by the Habibie Centre (THC), which is a think-tank institution in Indonesia, in early August 2015 in collaboration with the Henry Dunant Centre 
(HD Centre) Singapore. The project facilitated a study tour of the members of the Union Election Commission (UEC) from Rakhine State in order to learn about Indonesia's experiences to conduct peaceful elections in the post-conflict areas, particularly in Aceh and Ambon where segregation among the former conflicting parties still relatively exists. The delegation learned about the roles of the National Election Commission (Komisi Pemilihan Umum/KPU) and the National Election Monitoring Commission (Badan Pengawas Pemiliban Umum/Bawaslu), as well as the roles of the local NGOs and international NGOs to monitor the election process.

In terms of security sector reform, besides the usual military-tomilitary engagement mentioned earlier, there were some projects carried out by think tank institutions. For example, the Centre for Strategic and International Studies (CSIS) in Jakarta conducted two workshops on security sector reform in 2013 and 2014. The first workshop was held in Jakarta in September 2013, and attended by fifteen participants from Myanmar, comprised of ten high-ranking military officers and five representatives from think tanks and NGOs. The second workshop was organised in January 2014 in Yangon, through the collaboration with local NGOs, and attended by around thirty local participants comprised of high ranking military officers, police officers, parliament members, advisers to the President, and high ranking officers from the Indonesian Ministry of Home Affairs, as well as academics and NGOs representatives. In those two workshops, the Indonesian counterparts, especially the Indonesian retired generals who involved in the reform process shared about Indonesia's military transition process from the dual military system to becoming a professional military, democratic civilian control, human rights, as well as law enforcement to sustain peace process in conflict-prone areas. The Myanmar representatives specifically expressed their enthusiasm to learn from Indonesia's experiences in promoting conflict resolution in Aceh, specifically in regards to the Aceh insurgency from 1976 to 2005, as well as on addressing the root causes of other communal conflicts in Indonesia.

Another issue, which probably the most salient one in Indonesia's peacebuilding activities in Myanmar, is the commitment to assist the Myanmar government in dealing with problems related to ethnic groups, especially in relation to the controversial Rohingya issue. Members of the Muslim Rohingya community in Rakhine State in western Myanmar claim that they are a legal minority within Myanmar, but members of the Myanmar 
government do not recognise that status, and often eschew the very term 'Rohingya', instead referring to the persons in question as 'Bengali' and implying that they are migrants from neighbouring Bangladesh without claims to Myanmar citizenship. As a country with the world's largest Muslim community, Indonesia needs to address the concerns and pressures from its constituents at home to stop the massive violence and discrimination against the Rohingya ethnic group. Such pressures turned out to be a serious regional security threat as a group of Muslim extremists launched bomb threats against Buddhist religious facilities, as well as the Myanmar embassy in Jakarta, in 2013 (Institute for Policy Analysis of Conflict n.d.). At the same time, Indonesia also faces real challenges due to the influx in mid-2015 of Rohingya boat people from Myanmar entering into its territory by boats. Indonesia and Malaysia have so far agreed to provide temporary shelters for seven thousand Rohingya Muslims refugees and migrants from Myanmar and Bangladesh (Guardian 2015). However, violence in Rakhine state between Myanmar armed forces and Rohingya militants continues to plague the current Myanmar government.

Indonesia has provided development assistance to the Rakhine state in the form of financial and technical aid. While such action is not necessarily distinct, what is important to highlight is the way the Indonesian government took on a more balanced approach in order to quench the perception of Rohingya problem as a religious conflict of Muslims vs. Buddhists. Indonesia decided not to give support on the OIC's (Organization of Islamic Countries) approach to only aid the Muslim community in Rohingya, despite of its status as a member in the organisation, a move which would undoubtedly be rejected by the Myanmar government (IRIN News 2012). Indonesian Vice President Jusuf Kalla, who was the Chairman of the Indonesian Red Cross (PMI), back in 2012, stated that the PMI would be, by necessity, non-partisan in its assistance in Rakhine state, as he reflected on the ways which the Indonesian government addressed similar ethnic conflicts in Indonesia itself in the past (Taufiqurrahman 2012). One year later, Indonesia also built four schools in Rakhine state, using a donation from the Indonesian government with a total of US\$1 million (Antara News 2014). Two schools have been dedicated to the Muslim community while two others were built for the local Buddhist community.

Aside to government's efforts, NGO also plays certain peacebuilding role in dealing with ethnic problems in Rakhine state. Muhammadiyah, 
for example, as one of the largest religious based NGO in Indonesia has collaborated with other NGOs in the region, including one local NGO in Myanmar, to explore possible areas of peacebuilding where it can participate in dealing with the Rohingya issue. ${ }^{13}$

\section{Achievements/Measuring Results}

Despite Indonesia's active engagement in peacebuilding in Myanmar, so far the government has not developed any standard monitoring and evaluation mechanisms in order to measure achievements as well as to evaluate past mistakes/failures from the projects. It is indeed a challenging task to measure of what has been achieved so far from Indonesia's engagement in peacebuilding in Myanmar for two reasons. First, there is simply no standard mechanism created by the government to monitor and evaluate projects of this nature. What normally exists is internal project evaluation applied by the donor/funding institutions or agencies, which cannot be shared for public consumption. For projects implemented by government agencies/ministries, each implementing body or ministry usually does not have any obligation to conduct any monitoring and evaluation processes. Even if such monitoring does take place, the data collected is usually not shared with the public.

Second, and more importantly, Indonesia has been focusing its engagement more on the political aspects of the Myanmar reform process and long-term projects more than working on short-term and specific or clearly defined areas. The 'sharing' approach basically emphasizes the sharing of ideas, knowledge and experiences and it is almost impossible to measure it quickly to what extent such ideas or experiences have been taken and influenced the policies of the Myanmar stakeholders.

The best indicator to measure results or achievements, as suggested by Myanmar and Indonesian stakeholders, would be to see the level of trust and confidence shown by the elites in Myanmar towards Indonesia's active engagement in the country. For example, the interest expressed from high-ranking military officers, high-level public officials, and also recently from the representatives of ethnic groups from Myanmar to participate in various events that involved Indonesian institutions as resources have shown a considerable success. Based on the interviews with different Indonesian stakeholders, they have been urged to continue the projects or even to come up with new projects. ${ }^{14}$ But have we seen any changed behaviour? Interestingly, the request for more exchanges in the educational 
sector to better introduce Indonesia to more sectors of Myanmar society, especially among Myanmar's youth, can be seen from both sides. ${ }^{15}$ From a positive perspective, it can be another indicator that Myanmar society welcomes Indonesia's deeper engagement in the country, but from a more negative perspective we can also see that Indonesia's activities so far have only been concentrated on elites, and have not reached the greater Myanmar society, yet.

Such trust could also be seen in the most sensitive issue of ethnic relations in Rakhine state. While initiatives from many countries and international organisations to help were turned down by the Myanmar government, President Thein Sein formally asked Indonesia during the 21st ASEAN Summit in Phnom Penh in November 2012, despite the fact that the country is majority Muslim, to help his government in resolving ethnic tensions in Rakhine state (Santosa 2012).

Another interesting piece of evidence appeared when President Joko Widodo was received as the first guest, among other ASEAN countries, by President Thein Sein on the sidelines of the ASEAN Summit in November 2014 in Naypyidaw, although not many issues were directly discussed by the two leaders. Indonesia has been welcome to expand its economic engagements in Myanmar, as President Thein Sein has encouraged his Indonesian counterpart to increase its investments, particularly to take advantage of the new policy that allows foreign banks to operate in the country (Otto 2014).

One unanticipated positive result from these engagements, as argued by some Indonesian stakeholders, is that instead of Myanmar simply learning from Indonesia's experiences, a two-way learning process has evolved, in which Indonesia is also learning from its Myanmar counterparts. For example, according to Lt-Gen. (ret.) Agus Widjojo, who was actively involved in the Indonesian military reform process, Myanmar actually has a better sense of the supremacy of law as compared with Indonesia's political system. According to him, before the Myanmar military deployed in conflict-prone areas, such as in the northern regions, the government first issued a state of emergency status, while in the Indonesian case military action, in most cases, took place before issuing any regulations, placing the legality of the military actions into question right from the outset. ${ }^{16}$

Another example, as shared by a leading think-tank based in Jakarta, is the degree of openness shown by the stakeholders from Myanmar, including from some of the country's politicians. During one discussion held recently by the Habibie Center in Jakarta which addressed the topic on 
election in post-conflict areas, the participants were involved in a very frank dialogue, an outcome which was not really expected due to the sensitivity of the issue related to the minority group in Rakhine state. ${ }^{17}$

On the other hand, one of the concerns is about whether the high level of interest by Myanmar's military towards Indonesia's 'dual function' military policies in the past would suggest a delay in the process toward democratisation in Myanmar. At present, the constitutional amendment which requires twenty-five percent of seats in the upper and lower houses of the Myanmar parliament to be assumed by members of the Myanmar military will not be eliminated in the near future. Indonesia, by comparisons, is also struggling to ensure that its own democratisation process would not go backward. Former Indonesian Minister of Foreign Affairs Hassan Wirajuda described this description succinctly by noting:

During a workshop on security sector reform that I attended in Yangon earlier this year, senior Myanmarese military officers told me they had no intention of playing an active role in politics, unlike the Indonesian military of the past. [...] They continued to ask the Indonesians why in the wake of reform, our military was able to quickly withdraw from its political role in 2004 , because they said they didn't think they would be capable of doing it as fast as we did in Indonesia.

From the Indonesian side, we understood that their situation is different, but we reminded them that when Myanmar becomes a more democratic society in line with universal democratic values, the military will have to ultimately withdraw from the political stage. They are seriously considering this, but in terms of timing, it will not be as fast as what we achieved in Indonesia. This is nonetheless part of the process of Myanmar becoming an open and democratic society. (Wirajuda 2014)

Based on discussions with various Indonesian stakeholders, many challenges tend to come from within, rather than posed by the conditions in Myanmar. The first challenge is the view from some segments of Indonesian society that Indonesia is still far from having the capacity to project its own democracy and solutions to human rights problems, including some ethnic conflicts at home. Secondly, there is the problem of a lack of coordination among different agencies in Indonesia, especially among government institutions. Within the government, for example, while the Ministry of Foreign Affairs conducted its diplomacy activities to open up communications and gain trust from the Myanmar government, the other relevant ministries are not really following up to take advantage by bringing in more investments into the country in order to reap some tangible economic benefits. 


\section{China's Engageement in Myanmar}

\section{Strategic Objectives}

China is considered a 'new' actor in the Myanmar peacebuilding process despite the longstanding history between the two states since it has been only recently that Beijing has sought to modify its 'hands-off' approach to domestic politics in Myanmar and instead seek to participate more directly both in the war-to-peace transition in Myanmar as well as that country's economic reform processes. What also makes the China case distinct is that the PRC is widely acknowledged to be rising great power and potential challenger to American policies in Asia, and has been traditionally very sensitive to the security of its borders.

There has been a largely unbroken political partnership between the two states ever since Burma became one of the earliest governments to recognize the People's Republic in June 1950. Burma was also the first non-communist country to recognise the Maoist government in Beijing. Shortly afterwards, a period of what was called 'Pauk Phaw' (Sino-Burmese kinship) began, based on both states' support for the ideas of peaceful coexistence and decolonisation (Yue 2014). However, Sino-Burmese relations experienced difficulties, and Burma found it difficult to escape the political eddies which were buffeting its northern neighbour during the Maoist era. In the late 1980s, when Myanmar began a period of intensified diplomatic isolation, spearheaded by the United States and Europe. China was one of the few major countries to maintain political and economic relations with the military junta.

By the 1990s and after, there were growing impressions by Western observers and policymakers that Myanmar had become a de facto subaltern state to Beijing, an impression which has often been overstated given the more complex political relationship between the two governments during the cold war period. Military ties in the form of arms sales increased after that period, and Chinese legal and illegal migration to Myanmar also increased (Steinberg 2013).

Since the 1990s, energy cooperation has become a core interest in the Sino-Myanmar relationship. Oil and gas development projects proliferated, and in January 2015 the Maday Island oil pipeline which runs from the Myanmar coast to the Chinese city of Kunming in Yunnan province, formally began operations. Beijing has been seeking to develop alternative energy transit routes as an alternative to the Malacca Straits, through 
which about eighty percent of China's imported oil travels through from Africa and the Middle East (Meyer 2015). Despite the rapid drop in fossil fuel prices since the end of 2014 and the slowing Chinese economy in 2015, access to foreign energy supplies remains a priority for Beijing, given the inherent uncertainty of long-term access. Myanmar remains an important partner in the development of these alternative routes as China seeks greater access to the Indian Ocean and a diversification of trade routes both for trade and for energy imports from the Middle East and Africa.

Other areas of bilateral energy cooperation have been more problematic, such as the Myitsone hydroelectric dam project, located in Kachin State in northern Myanmar and worth about US\$3.6 billion and expected to provide power for China's Yunnan province upon completion. Construction began in December 2009, but further work has been in abeyance since September 2011 out of concerns from the Myanmar government about the environmental and political impact of the project. In June 2014, Chinese Premier Li Keqiang called upon the Myanmar government to restart the project, and Beijing remains hopeful that the construction can resume (Harvey 2011). Economic interdependence between China and Myanmar also grew considerably after the late 1980s, with Beijing seeing its southern neighbour as an idea test case for China's developing 'going out' (zouchuqu 走出去) policies of expanding Chinese business interests on the regional and international levels. In addition to Myanmar's utility as a transportation corridor into the Indian Ocean, Myanmar's supply of raw materials and fossil fuels were also of great interest to Beijing as the Chinese economy began its 'take-off' phase (Yun Sun 2015). In 1988, as Myanmar was sinking further into diplomatic ostracism, Beijing signed an enhanced trade agreement with its southern neighbour, legalising direct cross-border trade and opening the door to military aid from Beijing (Legene and Ytzen 2014).

Despite some political differences, China is also remains a major supplier of aid to the government of Myanmar, and here has been bilateral consultation on a variety of areas including industrial development, education, corporate social responsibility, and environmental protection. Much Chinese aid and assistance has been in the form of infrastructure, including transportation (roads and railways) as well as ports and communication. ${ }^{18}$ China has stressed the idea that peace and stability in Myanmar should be directly linked to combatting poverty and 
underdevelopment, especially in rural areas, and so much of China's economic assistance has focused on rural regions of Myanmar including in the north.

The border regions remain a security problem for both states, however, as illustrated for example by the 2009 Kokang Incident, when fighting between the Myanmar military and the rebel Myanmar National Democratic Alliance Army (MNDAA), a remnant of the CPB, resulted in an estimated ten thousand, and possibly as many as twenty thousand, refugees crossing the border into China's Yunnan Province. This was the largest refugee flow into China since the Vietnam conflict in the 1970s, and the numbers of refugees crossing into Yunnan caught Chinese officials completely off guard (Storey 2009; Thant Myint-U 2011). The 'Kokang Incident' also explained Beijing's ongoing interest in Myanmar peacebuilding. Any uptick in violence in northern Myanmar could result in further refugee flows into China at a time when Beijing was seeking to push forward austerity measures in the wake of its economic slowdown after 2014.

Border security continues to be a sensitive issue between Beijing and Naypyidaw. On the Myanmar side, there have been concerns expressed in Myanmar policy circles that Beijing was maintaining at least tacit support to armed rebel groups along the border, including the United Wa State Army (UWSA) in northern Myanmar (Lintner 2015). ${ }^{19}$ Myanmar officials have been concerned Beijing views these northern armies as potential bargaining chips in maintaining a solid diplomatic and economic relationship with its southern neighbour.

\section{Bilateral Economic Relations}

Despite the perception that China's influence would be seriously diluted in the wake of the opening of Myanmar to new trading partners, including the West, as well as developing political differences, overall trade has continued to be strong, jumping from US $\$ 4.9$ billion in FY 2012-3 to approximately US\$7.2 billion in FY 2014-5 (Central Statistical Organization 2015). The addition of new potential trade and investment partners in Myanmar may actually be an advantage, rather than a liability for China since a diversification of economic partners would dampen the impression among some Myanmar policymakers that Beijing has too strong an influence on the Myanmar economy. 
As well, the issue of illegal logging, supported by Chinese labourers, came into focus in July 2015 when 155 Chinese nationals were sentenced to life imprisonment for illegal logging activities in northern Myanmar, a case complicated by the fact that the Myanmar government was reportedly seeking to send out a warning to foreign actors not only about engaging in such activities but also about conducting private business deals with ethnic militias in the north. Although all the Chinese workers sentences were released as part of a widespread amnesty by the Thein Sein government later that month, the incident further chilled Sino-Myanmar economic relations (New York Times 2015). Chinese authorities also expressed disappointment at the slow pace of the Letpadaung copper mine project in the Sagaing Region of north-western Myanmar. Protests against the project have been common since 2012, and as one Chinese analyst argued, delays in the project could be traced to Myanmar's 'existing social contradictions' that specifically targeted Chinese business interests in the country (Song 2015; Parameswaran 2015). Overall, there does appear to be growing support within the government of Myanmar to better vary its trade partners.

China and Myanmar also have the opportunity to strengthen their economic relationship via new multilateral initiatives. Myanmar was a founding member of the Beijing-led Asian Infrastructure Investment Bank (AIIB) in March 2015, and Myanmar became an early potential recipient of development funding via the financial institution as the bank began operations in 2016. A US\$20 million power plant at Myingyan in the Mandalay region is currently under consideration for AIIB funding. ${ }^{20}$ China's 'Belt and One Road' (yidai yilu 一带一路), and its accompanying 'Silk Road Fund', with an initial value of US\$ 40 billion, organized by Beijing since 2013 may also be of future benefit to Myanmar. In an April 2015 interview with the Chinese news agency Xinhua, the Chair of Myanmar's ruling USDP and presidential candidate, U Shwe Mann, expressed appreciation for the Silk Road projects, which are very likely to involve Myanmar given the country's key geographic location (Wang 2015).

\section{Chinese Diplomacy before and after the Elections}

Although China wishes to maintain robust relations with the current Myanmar government, Aung San Suu Kyi, the head of the opposition National League of Democracy (NLD), was invited to Beijing in June 
2015 and had a direct dialogue with President Xi Jinping, a sign that China was still placing a great deal of importance on its Myanmar relations after the elections and is preparing for a time when the number of Myanmar's foreign policy links will grow and become more diverse.

Cognisant of the current challenges to its reputation in Myanmar, the government of China has sought to take more of a soft power approach towards its southern neighbour. First, Beijing has attempted to play a mediating role in the ongoing peace talks in Myanmar and has offered overall support for the successful completion of the negotiations. China, along with Thailand, has also hosted recent peace talks (Aung Naing Oo 2015). Second, the Chinese Embassy in Yangon has attempted to play a more active role in regional aid and assistance, as illustrated by the response of the Embassy to massive flooding which took place in western Myanmar in August 2015. Beijing released US\$300,000 in aid to the region shortly after the flooding began and the newly arrived PRC ambassador to Myanmar, Mr Hong Liang, personally oversaw the delivery of relief supplies to the storm-affected Sagiang region of the country, while individual provinces in China, including Yunnan, also sent aid and supplies (CCTV 2015). China has also been active in developing university exchanges, including with the University of Yangon, and seeks to promote further linkages among research institutions in Myanmar. ${ }^{21}$ It remains to be seen, however, to what degree Beijing's attempts at building soft power in Myanmar will counteract growing concerns about Chinese influence in the post- 2015 government and politics in the country.

\section{Chinese Views on Peacebuilding: Towards a Greater Pragmatism}

Since China joined the United Nations in 1971, there has been a significant evolution of Beijing's overall views on internal intervention in war-to-peace transitions, including in the areas of peacekeeping and peacebuilding. These views have greatly changed from negative to positive, as demonstrated for example in Chinese views on participation in United Nations operations. Once China began to participate in UN missions, there was a preference for sending observers only, during the 1990s, with one exception being the UN Transitional Authority in Cambodia (UNTAC) in 1992-1993 where two separate Chinese engineering battalions were deployed, becoming China's first true 'blue helmets.' At the turn of the century, China agreed to send civilian police units as liaisons to the UN mission in East Timor (Permanent Mission of PRC to UN 2009). 
These events suggested that Beijing was growing increasingly comfortable with peace operations under the UN banner, at least in East and Southeast Asia.

Under the administration of Hu Jintao (2002-2012), the Chinese government slowly began to accept both the concept of soft power in international relations and the debates behind it. However, there were occasional indications that Beijing viewed soft power, like hard power, as a source of competition and even possible danger. While the idea of soft power began to circulate in the United States and elsewhere in the West during the 1990s, the concept only began to make tentative appearances in Beijing official statements in the following decade. President $\mathrm{Hu}$, in one of the first official mentions of soft power, stated during a 2006 speech that 'how to identify the orientation of China's cultural development to create a glorious new national culture, and enhance the international competitiveness of our culture, to enhance the soft power of the State, is a major practical issue before us.' (People's Daily 2006).

However, once the concept of 'peaceful rise' began to be discussed at greater length by Chinese policymakers, soft power matters grew beyond questions of culture, becoming increasingly folded into spirited debate by both government and academia over what role soft power might play in gauging the country's overall power levels, especially vis-à-vis the United States. For example, in a landmark 2006 article on the subject of China's developing 'comprehensive national power' (zonghe guoli 综合国力), Yan noted that if soft power were to be added to the overall measurement of power levels, Chinese comprehensive power would still be 'inferior' to that of the United States (Yan 2006a, 2006b). Under the Hu government, international law, including the observance of UN protocols, was an increasingly visible part of China's views on foreign policy and international institutions as a way of improving this perceived shortcoming in comprehensive national power. Southeast Asia has become a crucial test case from Chinese attempts to improve its prestige and soft power, through various revised policies including developing a more nuanced approach to peacebuilding.

Soft power also began to be debated in China since the turn of the century within the framework of foreign policy development as the government considered the merits of continuing to adhere to the Deng Xiaoping-era doctrine of keeping a low global profile (Li 2008). Included was the question of whether China's rise meant that its foreign policy should focus on responsibility to match growing Chinese power. As China 
began to expand its foreign policy interests under President Jiang Zemin in the 1990s, the ideas stressed by Deng during the previous decade about maintaining a low profile and not taking the lead in international affairs, and 'hiding one's light' (taoguang yanghui 蹈光养晦) began to be viewed as less viable (Guo 2013). China, at this stage, was in the process of making its transition from 'large developing country' to 'rising power'. In Beijing's 2011 White Paper on 'peaceful development' (heping fazhan 和本发展), support for building a peaceful global environment was stressed along with the idea that China's armed forces would develop as a defensive force and support military exchanges and develop partnerships both on the regional and the international levels (PRC State Council 2011).

However, China's economic successes and its overall rise, it has been argued, have not removed international (and regional) concern about a possible 'China threat'. This has especially been an issue in the United States, where it was noted that a weaker and divided China tended to be viewed more favorably by the United States while, conversely, a strong and externally oriented China is looked upon more negatively. Thus, Beijing needed to seek ways of developing its strength while continuing to avoid the appearance of challenging the international order. This has proven difficult for a variety of reasons. First, China's rise has been both strategic and economic, with both 'rises' taking place very rapidly and affecting more and more of the international system. The current disputes between China and members of ASEAN, especially the Philippines and Vietnam, over maritime sovereignty in the South China Sea has accentuated concerns that China is playing more assertive and revisionist role in Southeast Asian security. As noted above, Myanmar is seeking to avoid being caught in regional disputes between Beijing and Southeast Asian governments and may be seeking to return to a more non-aligned stance in its foreign policy, placing greater distance between itself and China.

Second, China's military spending, while still nowhere near American levels, has nonetheless increased considerably under $\mathrm{Hu}$ Jintao and $\mathrm{Xi}$ Jinping, and has resulted in greater power projection capabilities, particularly at sea. This has led to questions about whether Beijing would seek to address long-standing maritime disputes as noted in the introduction to this paper, and even whether China would seek its own de facto version of a Monroe Doctrine, an implied sphere of influence in the western half of the Pacific (Yoshihara and Holmes 2011). Third, it was suggested that despite the country's soft power development there remained a high degree of foreign policy 'inconsistency' on Beijing's part, which has made it 
difficult for the Chinese government to make optimal use of its soft power (Gill and Huang 2009). This has been caused at times by nationalism, concerns over potential 'containment' policies by the West, and internal differences over the future direction of China's international relations. As such, one of the most visible ways by which Beijing is attempting to satisfy the dueling demands of building both military and soft power internationally, while under considerable global scrutiny, is through its commitments to UN peacekeeping.

China's increased engagement with international peacekeeping missions has been acknowledged as a necessary building block for the development of Chinese soft power, as well as promoting the idea of China as an 'internationally socialized country' (Guo 2007; Wuthnow 2008) and a 'responsible power'. The latter concept, facilitates the development of Chinese peacekeeping policy by allowing Beijing to define its own peacekeeping role, to further integrate into the international system without necessarily adhering to Western foreign policy models, to critique the international system, and to underscore that China is developing into an atypical great power which respects international sovereignty (Richardson 2011). Moreover, China's peacekeeping commitments since the 1990s have allowed that country's military to operate far away from Chinese soil without triggering anxieties from its neighbors or the United States in the wake of Beijing's expanded military budgets and capabilities.

By the beginning of this century, China was openly supportive of the peacekeeping idea both as a way of prompting peaceful multilateral settlement of disputes and as a means to include its armed forces in 'Military Operations other than War,' or Моотw, including humanitarian missions, disaster relief and increasingly peacekeeping missions. The concept was borrowed from American post-Cold War military terminology to refer to noncombat military operations (Gill and Huang 2009; Fravel 2011). Southeast Asia had been a major beneficiary of Beijing's changed views on peacekeeping, as Beijing was supportive of the development of the UN Transitional Authority in Cambodia (UNTAC) in 1992-1993 despite China's difficult history with that conflict. China was also willing to send civilian policy to assist with the United Nations Transitional Administration in East Timor (UNTAET), despite the fact that the major element of that deployment was to prepare for the independence of Timor-Leste (Lanteigne 2014). China has been traditionally wary of international intervention in separatist crises out of concern for precedent, 
but has begun to better differentiate between 'good' and 'bad' forms of intervention in the name of peacebuilding. War-to-peace traditions via the UN are considered ideal models for China and far better options than unilateral or great power-led peacebuilding initiatives. For example, Beijing was highly critical of NATO operations in Serbia-Kosovo in 1999, and more recently the American and European operations which toppled the Gaddafi government in Libya in 2011, actions which Beijing blames for starting the ongoing civil war there.

A major element of China's success in developing its peacekeeping practices as a factor in its soft power development is that the country has consistently approached overall peacebuilding practices via policies more consistent with 'middle-power' status rather than that of the great power it was quickly developing into. Beijing's lack of history as a colonial power, and its policies dating well back to the Maoist era of solidarity and support for developing countries and regions including in South and Southeast Asia, (the so-called 'Bandung Spirit' of the mid-1950s) (Cao 2005), have helped underscore the perceptions which Beijing is seeking to put forward that China as a state that eschews the great power chauvinism and at times hegemonic conduct of previous great powers, especially the West.

In its diplomacy in developing countries, China retains many vestiges of previous 'large developing country' thinking which, in the case of its peacekeeping and peacebuilding policies, have served Chinese interests very well. However, in light of China's increasing power and growing ever closer to traditional great-power status, an argument can be made that the country's middle-power approach to peacekeeping may be less viable in the future. This would have an adverse effect on China's ability to promote peacekeeping as a key component in its soft power development. Nonetheless, China continues to maintain ties between soft power development and engagement with various forms of peacebuilding/warto-peace transition policies. In September 2015, this commitment was further underscored during President Xi's speech to the United Nations General Assembly. Xi offered to commit eight thousand Chinese personnel for a standby UN peacekeeping force, as well as offering greater support for Un requests for engineering and medical staff, on the condition that 'exit strategies needed to be timely formulated and executed.' (Martina and Brunnstrom 2015). 


\section{China and Myanmar Peacebuilding}

As a core member of the group of actors seeking to shepherd a successful cease fire agreement in Myanmar in the next year, Beijing has attempted to soften its reputation in the country in the wake of mistrust both from elements of the Myanmar government and the public, while at the same time discourage a 'Western drift' in Myanmar's foreign relations given the important role the country plays in China's future regional development plans. As well, the events since the beginning of 2015 have also underscored the close connection between China's southern border security and the successful completion of the peace process. Due to its sensitivity to being perceived as a spoiler or a revisionist power in all four streams of the Myanmar peace process, China has chosen to emphasize the role of education, anti-poverty measures, and infrastructure in Myanmar as its main contributions to the peacebuilding process.

These approaches have been in keeping with its traditional policies of aid and assistance which favour keeping a strong separation between governance and economics, while also drawing a distinct connection between poverty and underdevelopment on one side and insecurity on the other. As noted above, Beijing is also stressing that it is willing to work with any successor government after the November 2015 vote, as illustrated by the willingness of the $\mathrm{Xi}$ government to open communications with the NLD and Ms Suu Kyi. At the same time, China is also developing a peacebuilding policy in Myanmar that incorporates sub-governmental activities including educational and training programmes in rural regions, especially in the northern provinces, to stress the need for more balanced development in the country. ${ }^{22}$

China, as a participant in the ceasefire process in Myanmar, has also been notably active in calling for an end to hostilities between the MNDAA and the Myanmar government as part of Beijing's desire to pacify the border between the two states. In June 2015 it was announced that a ceasefire would go into effect after four months of coercive diplomacy by China (McLaughlin and Zaw 2015). Beijing continues to support a wider pacification of the Myanmar border region s through the development and signing of a National Ceasefire Agreement (NCA). According to Chinese officials based in Yangon and Jakarta, China has approached the Myanmar peacebuilding process based on its traditional views of the sanctity of state borders and a high regard for sovereignty and the rights of the people of Myanmar to take the lead in their political interests. As well, China 
remains Myanmar's top trade partner and has been in the best position to promote economic development in the country. China's interest in developing a strong ceasefire, according to Beijing representatives, was the concerns that the border region become stable and open to legal cross-border trade. China has also been a supporter of the BCIM (Bangladesh, China, India, Myanmar) trade corridor as part of Beijing's views that anti-poverty policies and peace are closely linked.

However, according to many persons interviewed in Yangon, China still has much work to do in promoting itself as a force for peace and stability given its long history with the military governments in Myanmar. A senior member of the ceasefire negotiation team, representing the Myanmar Peace Centre, issued a statement in September 2015 that Beijing was interfering with the process and encouraging two groups, the United Wa State Army (UWSA) and the Kachin Independence Organization (KIO) to eschew an agreement out of a desire to keep a high degree of control over the China-Myanmar border region. These charges were vehemently denied by Beijing, with the government stressing its support for a complete and comprehensive cessation of hostilities throughout Myanmar (Wee 2015; Meng 2015).

\section{Comparative Cases of Peacebuilding Actors}

\section{Norway}

Norway has developed a longstanding, if at times controversial, relationship with the governments of Myanmar over the past decade. The country developed a reputation for being an 'honest broker' due to its willingness to communicate and negotiate with the pre-reform military governments in Myanmar. With the 1991 Nobel Peace Prize being awarded to Aung San Suu Kyi (2010), Norway had been viewed as helping the question of the peace process of Myanmar to gain further international stature. Some Myanmar opposition figures have been unhappy with the decision by Oslo to meet directly with the military government of Myanmar, but Norway has established itself as a key mediator in the peace process. Norwegian businesses, most notably the telecommunications firm Telenor, also have a high profile in Myanmar (Telenor 2017). However, with the reform process continuing and with other countries in Europe, such as Germany, increasing their contacts with Myanmar in recent years, there is the question of whether Norway's special role in the country can be maintained. 
Norway played a primary coordinating role among donors in Myanmar around peace issues. On the governmental level, there has been much in the way of institution-building between Norway and Myanmar in the area of peacebuilding. For example, Norway established the twin institutions of the Myanmar Peace Support Initiative (MPSI) and the Peace Donor Support Group (PDSG) in 2012 at the request of Myanmar authorities (Government of Norway 2013). The MPSI was established to engage the Myanmar government, the country's military, as well as non-state armed and political groups, civil society actors and communities, in addition to international actors, to provide concrete support to the ceasefire process and emerging peace process. Various projects have been initiated via the MPSI in ceasefire areas and in conjunction with relevant stakeholders.

Yet, the reputation of Norway in Myanmar as a peacebuilding actor has been mixed in recent years largely due to the approach which Oslo has taken regarding direct contacts and mediation efforts with the disputants in Myanmar. It has been argued that Norway's 'normative' approach to the peacebuilding process in Myanmar was conducted along similar lines as Norwegian mediation activities in Sri Lanka during that country's long civil conflict (Sánchez-Cacicedo 2014). While Oslo distinguished itself among other Western actors, including the United States, Australia, Canada and other Western European countries, which largely sought to isolate the military regime in Myanmar since the 1990s, Norway's status as a 'white knight' did fall under some criticism from some actors in Myanmar and elsewhere in Asia both for Oslo's willingness to engage with political and military institutions in the country which have been accused of gross misconduct, but also that Norway's approach has lacked depth and greater understanding of political and socio-economic conditions 'on the ground', especially in the embattled northern regions on the country. ${ }^{23}$

Nonetheless, Norway has maintained a distinct status in the country both as a result of its peacebuilding efforts and the legacy of the Peace Prize, an act which brought the political and security situation in Myanmar to global attention and prompted greater international pressure for Ms. Suu Kyi's release and for reforms both in governance and foreign policy as well as a halt to the ethnic conflicts in the country (Johnsen 2015). Ms. Suu Kyi was finally able to accept the Prize in person in Oslo in 2012. In her speech, she stated, 
The Burmese concept of peace can be explained as the happiness arising from the cessation of factors that militate against the harmonious and the wholesome. The word nyein-chan translates literally as the beneficial coolness that comes when a fire is extinguished. Fires of suffering and strife are raging around the world. In my own country, hostilities have not ceased in the far north; to the west, communal violence resulting in arson and murder were taking place just several days before I started out on the journey that has brought me here today. (Suu Kyi 1991)

Norway has been seeking to develop its soft power in the months leading up the elections, through various forms of aid and assistance to urban and rural areas as well as relief efforts in the wake of the August 2015 cyclone and subsequent flooding in the western regions of Myanmar. The government of Norway pledged NoK10 million (US\$1.2 million) in aid to the region after the flooding began, and has worked towards better early warning facilities in order to reduce the number of casualties after future such disasters. However, other donations which Oslo made to Rakhine State were met with some criticism in Myanmar due to concerns this aid was favouring the Rohingya peoples, which are not considered a legal minority by authorities in Myanmar, and in a broader sense that Norwegian businesses were profiting on the coattails of Oslo's role in the peace process (News and Views from Norway 2014; McGregor 2015 ) Two Norwegian firms which have greatly increased their visibility in Myanmar since the peace process began has been the telecommunications corporation Telenor and the state energy firm Statoil. In 2015, an agreement was pending to allow Statoil access to a maritime block in order to survey for potential oil and gas.

There have been calls, especially from local educational actors, for Oslo to better diversify its aid and assistance portfolio in Myanmar by offering greater research links, student and faculty exchanges, and joint programmes in the country. ${ }^{24}$ There are plans for the Norwegian Embassy in Yangon to move within the city to a more central location, and to be based within a 'Nordic House' which would share facilities with the embassies of Denmark, Finland and Sweden, presenting more of a Nordic model of diplomacy to Myanmar. ${ }^{25}$ Norway has been caught up in the final states of the National Ceasefire Agreement, as some of the ethnic minority actors involved have requested that Oslo, along with the United States, Great Britain, Japan and the European Union be included. Earlier in 2015, the government of Myanmar agreed to expand the list of witnesses from solely the United Nations, ASEAN and China 
to include Thailand and India (Lun Min Mang 2015). Norway, however, was accepted by the Myanmar government as an election observer for the November 2015 vote, along with the European Union, Canada and Switzerland (Bangkok Post 2015). Although Norway may find itself having to compete with a larger array of foreign partners in Myanmar, including other Western European actors such as the UK and Germany, should the reform processes succeed and the peacebuilding process take root, Oslo is still in a strong position to maintain a distinct peacebuilding identity in Myanmar.

\section{India}

India has developed particular interests toward Myanmar, especially after the implementation of its 'Look East' policy in the early 1990s. Although India is the largest democracy in the world, its engagement with Myanmar has focused on economics and development, with no deliberate promotion of democratic values even during the opening process in Myanmar five years ago. While New Delhi has been open to the idea of 'sharing' its democratic experiences, the Indian government has insisted that the initiative should purely come from Myanmar, and that nothing should be done before India sees a more positive signal from Myanmar. As one regional specialist noted, India's initiative to promote democracy abroad is based on 'realist' political concerns, which emphasises the country's strategic aims, especially countering the expansion of Chinese influence in the Southeast Asian region and gaining support in the fight against separatist forces in the Indian northeast, and economic interests rather than an idealistic motivation (Cartwright 2009).

Second, in spite of the great improvement in relations between India and Myanmar, especially due to the investment activities in infrastructure including road and air links, banking services, and information technology, the Myanmar government has been very careful to balance its relations with India by continuing to engage with China. Yet, at the same time, Myanmar is trying as much as possible to maintain this delicate balance in order not to step between these two rising Asian giants. Therefore, as argued by Kanwal (2010), Myanmar's deliberate engagement with China, framed in economic and military cooperation, has been particularly aimed to 'keep India off balance and prevent its rise as a competing regional power.' Although it has been suggested that New Delhi will benefit by default from the current expansion of Myanmar's foreign policy interests and desire to move away from an overdependence on Beijing, there has 
been little sign that India is any position to directly compete with China on the economic or diplomatic front, and there are perceptions in Myanmar that India is more interested in balancing Chinese influence than deepening long-term investment in Myanmar (Jaishankar 2015).

Indian interests in peacebuilding in Myanmar have been framed by a strong perceived link between promoting economic development and regional stability and a consolidation of the war-to-peace transition in Myanmar. Before the military era, Indian entrepreneurs had an high profile in Burma, especially in Yangon, but cross-border relations foundered by the 1980s and did not recover until the beginning of the reform era and a thawing of relations in the wake of then-Myanmar President Thein Sein's visit to Delhi in 2011 when the beginnings of potential joint projects were discussed. The focus in India regarding Myanmar is about 'connectivity', meaning the building of roads, other transportation links and communications between the two states to promote trade and cooperation. ${ }^{26}$ Related to these areas has been the prospect of developing links based on IT, financial institutions and tourism. In regards to the disarmament process, India is not a part of the cease-fire negotiations, unlike China, and New Delhi has expressed concern about the security situation in western Myanmar and especially Rakhine, (although specific mention of the Rohingya issue was avoided). Although Indian officials are reluctant to speak about diplomatic and strategic competition with China, there is an economic dimension to India's engagement of the region, including participating in the port project at Sittwe on the Bay of Bengal. Among Myanmar officials spoken to, there was some lingering scepticism about whether India's burst of diplomatic and economic activity in Myanmar is a direct product of the desire to 'check' Beijing in the Indian Ocean.

As well, India and Myanmar are still addressing border security differences, as well as lingering Burmese traditional resistance toward the Indians inherited from the unfortunate position of the Indians during the colonial era. It has been estimated that there are as many as one million Myanmarese of Indian origin. India's infrastructure projects are still relatively low-key and peripheral, (i.e. only situated at the border areas), compared to China, for example. Furthermore, Indian development assistance in order to improve the education and health conditions in Myanmar, hampered by low transnational connections between Indian NGOs and Myanmar NGOs, have not been sufficient to overcome its deep-rooted image deficit there (Egreteau 2011). Thus, such conditions have limited India's role, especially in peacebuilding in Myanmar. 


\section{Japan}

Japan and Myanmar have a long post-WWII history of engagement. Japan was an occupying power during the Second World War between 1942 and 1945, but between 1955 and 1988, Japanese aid to the country was estimated at US\$2.2 billion, and until 1988 Tokyo was by far the largest aid and trade partner under the military-socialist era in Burma between 1962 and 1988. During that period, the Burmese government embarked on a de facto 'Look East' policy with a strong emphasis on deepening ties with Tokyo.

However, as a result of the military coup and the beginning of the SLORC government in 1988, Tokyo soon lost much diplomatic and economic ground for many reasons. First, under Japanese law, Burma had to be re-recognized under the new military government, which caused legal and political red tape for almost a year after the coup. Second, the SLORC government was less inclined to view Japan as a key economic partner than its predecessor. Finally, the United States placed heavy pressure on Japan to join in the West's sanctions regime against the SLORC government, badly weakening Tokyo's economic presence in the country. Even today, there remains a bilateral diplomatic dispute as a result of the shooting of a Japanese journalist during the 2007 'Saffron Revolution' protests in Yangon, an incident which the Myanmar government has yet to make a formal apology for. Tokyo is therefore in a strong position to play a greater peacebuilding role in the future given Japan's growing economic interests in the Myanmar reform process.

Although Japanese trade with Myanmar remains smaller than China's, and has been rising at a much slower rate, estimated at only US\$500 million in 2008, but rising after the reforms began to coalesce to US $\$ 1.5$ billion in FY 2012-3 and then rising to US\$1.7 billion in FY 2014-5 (JETRO 2014; CSO 2015), Tokyo has greatly increased its aid and development presence in the region since the 2011 reforms began. Summit diplomacy in Myanmar has also been a priority for Japan, as Prime Minister Shinzō Abe has made two visits to Myanmar during his second term in office. The first visit was in May 2013 when he agreed to write off about US\$2 billion in remaining Myanmar loans to Japan while announcing new aid initiatives, and the second took place in November 2014 when new overseas development assistance loans for infrastructure improvements were announced. ${ }^{27}$

Other Japanese projects elsewhere in Myanmar included loans for improving communications in the capital of Naypyidaw, providing road 
construction equipment in Rakhine and weather monitoring systems for various parts of the country. Japan has also been active in developing infrastructure in Yangon, providing new grants via the Japan International Cooperation Agency (JICA) for waterworks, hospital upgrades and bridge construction, and providing technical assistance with Yangon port facilities upgrades and the Greater Yangon Urban Development plan since 2012.

In terms of more direct participation in peacebuilding initiatives in Myanmar, Tokyo is a member of the Peace Support Group (PSG) in the country along with the United States, Australia, Canada, the EU, Norway and Switzerland. During the signing of the cease-fire between the government of Myanmar and eight of the ethnic armed groups from the northern edges of the country, the Government of Japan was a participant in the signing, as well as the Nippon Foundation, a philanthropic organisation with longstanding interests in the peace process (Factiva 2015). However, according to the Irrawaddy news service, Japan's deeper participation in the peace process has been hampered by opposition from China, which has been against the inclusion of Japanese and Western actors into the ceasefire negotiations (Aung Zaw 2015).

\section{Switzerland}

In keeping with Switzerland's venerable foreign policy of neutrality, which had been in place for centuries and had been codified and internationally recognised after 1815 (Church and Head 2013), the country has sought to play a peacebuilding role in Myanmar through programs oriented towards arbitration and education. Switzerland has been active in the current preparations for the Myanmar elections by developing activities through the Swiss Agency for Development and Cooperation (SDC) and other parts of the Swiss government to assist with voter preparation and education. Switzerland has called for ongoing dialogue between all major actors in the electoral process, including political parties, election officials, the media, and civil society organisations. In conjunction with the government of Germany and the International Labour Organisation (ILO), Switzerland has also been teaching vocational skills in Myanmar, including in areas of industry and tourism.

Myanmar peacebuilding projects undertaken by the Swiss government have included drafting a Code of Conduct (CoC) in October 2014 for all participating political parties, (estimated to number about ninety by August 2015), in the November 2015 elections, educating voters and parties on 
the democratic process, and supporting civil society and media organisations. These projects were undertaken using a 'hands-off' approach which specifically avoids any impression of political bias according to one Swiss official. ${ }^{28}$ Among the provisions of the $\mathrm{CoC}$ are pledges for all parties to respect the right to peaceful assembly and campaign activities, to settle disputes between parties in a cordial fashion, to avoid tactics synonymous with slander, to avoid discrimination during campaigning as well as the visible display of weaponry, and to avoid intimidation and dissemination of false information (FDFA 2014; Swissinfo 2015). The Embassy has also established mobile units for education on voter rights and responsibilities to more remote regions of the country. Plans are also underway for educational exchanges which would allow students to learn about politics and democratisation in Geneva and Bern. These courses would include case studies of federalism, which until recently had been a politically off-limits subject in Myanmar since for many years the military government in the country equated federalism with a unacceptable level of power devolution and a heightened risk of ethnic separatism. ${ }^{29}$

However, the spirit and letter of the $\mathrm{CoC}$ were threatened by laws which were implemented by the Myanmar government in the months leading up the elections, including a controversial ban on political parties from criticising the armed forces as well as disrespecting the country's 2008 constitution which guarantees the reservation of one-quarter of all seats in the upper and lower houses of the Myanmar parliament for the Myanmar Armed Forces/Tatmadaw (Slodkowski and Aung Hla Tun 2015). These restrictions, however, did very little to prevent the electoral landslide by the NLD after the November 2015 vote.

A large majority of political parties agreed to abide by the $\mathrm{CoC}$ and to participate fairly in the process. Switzerland has also been a supporter of human rights development in the country, and has advised on the Myanmar peace process via the Foreign Affairs Ministry's Human Security Division (HSD) (FDFA 2013). In the area of economic assistance, Switzerland has especially concentrated its Myanmar aid programmes in the country's south-eastern regions, including Kayin and Mon provinces. This region was chosen due to its compatibility with Swiss development initiatives for Myanmar, including promoting cohabitation between majority Burmese and ethnic minority groups, the possibility of a special economic zone being created in the Dawei region, and the promotion of legalised cross-border trade between Myanmar and its neighbours to the east, specifically Thailand. 


\section{LESSONS LEARNED}

The fieldwork completed for this chapter suggests a great deal of policy similarities between so-called 'old' and 'new' actors in Myanmar peacebuilding. Thus, collaboration between traditional actors and new actors is the most ideal framework to maintain, but the process should be undertaken on as much of an equal footing as possible. New(er) actors have the comparative advantage of having not too distant memories/experiences, or even still struggling with their own peacebuilding processes, as in the case of Indonesia:

1. Still relatively applicable for the host country.

2. New actors have more ability to have 'empathy' with the host countries as they might also encounter the same problems/challenges before.

3. Having the advantage to come in the position to 'dictating' or 'prescribing' but rather 'sharing' lessons learned, experiences, including past mistakes-equal footing.

China, as well, is addressing Myanmar peacebuilding with a great deal of local and regional concerns:

1. Safety of the Sino-Myanmar border, while ensuring cross-border trade can continue and grow.

2. Stress over the rights and responsibilities of being a great power in East Asia and moving away from its persons of being a large developing state.

3. Ensure it retains a place in the peacebuilding process despite the rapid introduction of new actors, including Japan, into the peacebuilding milieu.

4. Developing a more congenial identity in Myanmar after years of strong relations between Beijing and the Myanmar military regimes.

Traditional actors, on the other hand, also have their own comparative advantages, (including 'first mover' advantages which have been a boon some actors including Norway). These include:

1. Capacity to provide funding and related support 
2. Ability to develop a more systematic approach with clear instruments to measure achievements and results.

3. Have more energy to focus on peacebuilding efforts abroad since the developed countries have settled their own peacebuilding process long-time ago.

\section{Conclusion}

On 8 November 2015, Myanmar held the second democratic election after the result of the first multi-party election in 1990 was cancelled by the military junta. Earlier anxieties that this election would end up in the same fate proved to be wrong as the ruling military government under the leadership of President Thein Sein congratulated the National League of Democracy as soon as the result indicated a landslight victory for Aung San Suu Kyi's party.

The Indonesian government, through the press statement released by the Foreign Ministry expressed appreciation for the peaceful election process taken place in the country. More importantly, Indonesia has reiterated its commitment to continue to suppport Myanmar in its efforts towards sustainable reform and democratization, through cooperation in bilateral and ASEAN framework (Kemlu 2015). However, such statement, according to certain element in Indonesia has been considered as not only too late as it was released almost in the end of the month, but even worse was failed to send a clear message to indicate Indonesia's 'constructive engagement' approach to ensure the democratization process to be still on track. Such message is crucial because Indonesia, as elucidated in the editorial of the Jakarta Post published on 12 November 2015, is "constitutionally and morally responsible for helping all parties in Myanmar, including its army generals, reach this goal, no matter how painful the sacrifices they have to endure during the transition to democracy." (Jakarta Post 2015) With this clear trajectory, then Indonesia can maintain its proactive role to continue sharing its experiences in sustaining democracy in the country.

Looking at the existing challenges faced by the country, it is most likely that its foreign policy will seek to invite more investments from different countries to pour into the country to boost its economic growth. But, at least there is one common position between the NLD and the Indonesian government regarding the foreign policy direction. Based on the 2015 Election Manifesto of the NLD, foreign policy will be directed to 'pursue an active and independent foreign policy, and to establish friendly and 
close political relations.' (NLD 2015) On this point, this is a good beginning for the two countries to enhance their cooperation into a higher level, especially to maintain ASEAN unity the midst of competition among the major powers to spread their influences in the Southeast Asia region. However, the new Myanmar's leadership interest towards ASEAN remains in question mark since the regional organisation has been perceived as being too accommodative to the military junta regime in the past due to non-interference principle upheld by ASEAN, which then limited its interactions with NLD as the opposition party at that time. (Myint Thin 2013)

\section{Notes}

1. The founding members of ASEAN when the organisation was created in August 1967 were Indonesia, Malaysia, the Philippines, Singapore, and Thailand.

2. Indonesia donated around 22.4 tonnes of food, clothes and medicines and deployed medical team comprised of 30 personnel. See "TNI Hercules Delivers Humanitarian Aid to Myanmar [Hercules TNI Angkut Bantuan Kemanusiaan ke Myanmar]," http://tni.mil.id/view-9696-hercules-tniangkut-bantuan-kemanusiaan-ke-myanmar.html, accessed March 27, 2017

3. Interview with Chief Military Training, Myanmar Armed Forces, August 2015.

4. Interview with Lt. Gen. Agus Widjojo, August 12, 2015.

5. Interview with Hassan Wirajuda, August 11, 2015.

6. Interview with Hassan Wirajuda, August 11, 2015.

7. Interview with MoFA, Directorate of East Asian and Pacific Affairs, August $10,2015$.

8. Interview with Hassan Wirajuda, August 11, 2015.

9. In some capacity building projects, such as in agricultural sector, economic development, women's empowerment were funded by the Indonesian government. However, for trainings and workshops related to peacebuilding were funded externally from the third parties. The Institute for Peace and Democracy, for example, has been working closely with funding agencies from Australia, Denmark, Japan, the Netherlands, New Zealand, Norway, the United States and the European Union. Then, the latest specific training organised by the Indonesian government for the Myanmar police was supported by the government of the United Kingdom.

10. So far, 58 countries have been listed as participants, namely Indonesia, Afghanistan, Armenia, Australia, Azerbaijan, Bahrain, Bangladesh, Bhutan, Brunei Darussalam, Cambodia, China, Fiji Islands, Georgia, India, Iran, Iraq, Japan, Jordan, Kazakhstan, Kiribati, Republic of Korea, Kuwait, 
Kirgyzstan, Lao PDR, Lebanon, Malaysia, Maldives, Marshall Islands, Micronesia, Mongolia, Myanmar, Nauru, Nepal, New Zealand, Oman, Pakistan, Palau, Palestine, Papua New Guinea, The Philippines, Qatar, Russia, Saudi Arabia, Singapore, Solomon Islands, Sri Lanka, Tajikistan, Thailand, Tonga, Timor Leste, Turkey, Turkmenistan, Tuvalu, United Arab Emirates, Uzbekistan, Vanuatu, Vietnam, Yemen. See https://bdf. kemlu.go.id/about/participants, accessed March 27, 2016.

11. From 26 August to 1 September 2012, IPD in collaboration with the Presidential Advisory Council of Indonesia and the Indonesian Embassy in Yangon visited the country to conduct the scoping mission. During the visit, the Indonesian delegation, et with the Advisors of the President of Myanmar, the Myanmar National Human Rights Commission, Myanmar Development Resources Institute, Group of Democracy (the group of political parties in Myanmar) and the Union of Election Commission. See http://www.ipd.or.id/democratic-transition-in-myanmar.htm, accessed March 27, 2016.

12. Interview with former Indonesian Ambassador Sebastianus Sumarsono. The ambassador managed to do the observation in the Northern part, while other officials went to the South, West, East and Cental regions.

13. Muhammadiyah activists have involved in intensive communications with colleagues from the Center for Peace and Conflict Studies (CPCS) and The Center for Diversity and National Harmony (CDNH) and given access to utilise the Need Assessment Report of the Rakhine Province regarding peacebuilding in the area which can be used in creating the action plan for Muhammadiyah's participation in dealing with Rohingya problem.

14. For example, CSIS has received urgent request to continue its activities in Myanmar by creating a project to share its experiences in managing ethnic relations in conflict-prone areas.

15. Interview with some lecturers in Department of International Relations from Yangon University, August 2015.

16. Interview with Lt. Gen. (ret) Agus Widjojo, August 2014.

17. Interview with Habibie Center, August 2015.

18. Interview with Chinese government officials, Yangon, August 2015.

19. Bertil Lintner, "Same Game, Different Tactics," The Irrawaddy, July 2015, 14-19.

20. Interviews with Chinese Embassy officials, Yangon, April 2015; "Myanmar: Myingyan Power Plant Project," Asian Infrastructure Investment Bank (AIIB), https://www.aiib.org/en/projects/approved/2016/myingyanpower-plant.html, accessed September 26, 2016

21. Interviews with administrators at the University of Yangon, Yangon, August 2015. 
22. Interviews with Chinese Embassy officials, Yangon, April 2015.

23. Interviews with Myanmar policy officials and education specialists in Yangon, August 2015; Interviews with Myanmar foreign policy specialists, Beijing, July 2015.

24. Interviews with education officials and lecturers, University of Yangon, August 2015.

25. Interviews with Norwegian Embassy officials, Yangon, August 2015.

26. Interview with senior Indian Embassy official, Yangon, August 2015.

27. Interviews with Japanese Embassy officials, Yangon, August 2015.

28. Interview with senior Switzerland Embassy official, Yangon, August 2015.

29. Interviews with Embassy of Switzerland officials, Yangon, August 2015.

\section{REFERENCES}

Anwar, Dewi Fortuna. 2005. Indonesia at Large: Collected Writings on ASEAN, Foreign Policy, Security and Democratisation. Jakarta: The Habibie Center.

Aung, Naing Oo. 2015a. Armed Conflict: The Beginning of the End. Myanmar Times, August 25. http://www.mmtimes.com/index.php/opinion/16137armed-conflict-the-beginning-of-the-end.html

Aung, Zaw. 2015b. Of Pomp and Peace. The Irrawaddy, October 16.

Cao, Desheng. 2005. 'Bandung Spirit' Lives on after 50 Years. China Daily, April 19.

Cartwright, Jan. 2009. India's Regional and International Support for Democracy: Rhetoric or Reality? Asian Survey 49(3): 403-428.

Central Statistical Organisation. 2015. Ministry of National Planning and Economic Development. Myanmar. Accessed September 2, 2015. https:// www.csostat.gov.mm/sl.4MA0201.htm

Chachavalpongpun, Pavin. 2010. Last Bus to Naypidaw. In Myanmar/Burma: Inside Challenges, Outside Interests, ed. Alexis Rieffel. Washington, DC: Brookings.

Church, Clive H., and Randolph C. Head. 2013. A Concise History of Switzerland. Cambridge and New York: Cambridge University Press.

Dunia. 2014. Jokowi: Indonesia to Invest in 3 Sectors in Myanmar [Jokowi: Indonesia Investasi 3 Sektor di Myanmar]. Tempo. November 12, 2014. Accessed November 15,2014 . http://dunia.tempo.co/read/news/2014/11/12/118621420/ jokowi-indonesia-investasi-3-sektor-di-myanmar

Egreteau, Renaud. 2011. A Passage to Burma? India, Development, and Democratization in Myanmar. Contemporary Politics 17(4, December): 467-486.

Federal Department of Foreign Affairs (FDFA), Switzerland. 2013. Swiss Cooperation Strategy Myanmar, 2013-2017. Accessed July. https://www.eda. 
admin.ch/content/dam/deza/en/documents/Laender/Swiss_Myanmar_ strategy_2013_2017.pdf

. 2014. Code of Conduct for Political Parties and Candidates. Accessed October. https://www.eda.admin.ch/content/dam/countries/countriescontent/myanmar/en/Code $\% 20$ of $\% 20$ Conduct $\% 20$ for $\% 20$ Political $\% 20$ Parties\%20and\%20Candidates_Eng.pdf

Firdaus, Farid. 2015. Lippo Group Inaugurates First Myanmar Hospital, Plans \$1b Investment. The Jakarta Globe, June 7. http://thejakartaglobe.beritasatu.com/ news/lippo-group-inaugurates-first-myanmar-hospital-plans-lb-investment/

Fravel. 2011. Economic Growth, Regime Insecurity, and Military Strategy: Explaining the Rise of Noncombat Operations in China. Asian Security 7(3): 177-200.

Garuda Indonesia. 2015. The Strategic Cooperation will Further Strengthen Both Airlines' Flight Network and Provide Seamless Yet Convenient Connections between Indonesia and Myanmar. Accessed March 27, 2017. https://www. garuda-indonesia.com/id/en/news-and-events/Garuda-indonesia-myanmarairways-tandatanganikerjasama-codeshare.page

Gill, Bates and Chin-Hao Huang. 2009. China's Expanding Peacekeeping Role: Its Significance and Policy Implications. SIPRI Policy Brief, 1-7 (February).

Guo, Shuyong. 2007. Xin guoji zhuyi yu ruan shili waijiao [The New Internationalism and China's Soft Power Diplomacy]. Guoji guancha [Global Perspective] 2.

Guo, Sujian. 2013. Chinese Politics and Government: Power, Ideology and Organisation. London and New York: Routledge.

Harvey, Rachel. 2011. Burma Dam: Why Myitsone Plan is Being Halted. BBC News, September 30.

Htoo, Thant. 2015. Police Study Up on Election Rules. Myanmar Times, February 27. http://www.mmtimes.com/index.php/national-news/13252-police-gettraining-ahead-of-election.html

Indonesian Embassy [Kedutaan Besar Republik Indonesia]. 2001. Sang Merah Putih di Tanah Pagoda: Kenangan, Masa Kini, dan Harapan [The Red and White (Indonesian Flag) in the Pagoda Land: Memory, Now, and Future]. Yangon: Indonesian Embassy.

Institute for Policy Analysis of Conflict. n.d. Indonesian Extremists and the Rohingya Issue. http://www.understandingconflict.org/conflict/read/9/ INDONESIAN-EXTREMISTS-AND-THE-ROHINGYA-ISSUE

Jaishankar, Dhruva. 2015. Myanmar is Pivoting Away from China. Foreign Policy, June 15. http://foreignpolicy.com/2015/06/15/myanmar-burma-is-pivotingaway-from-china-aung-san-suu-kyi-xi-jinping-india/

Japan External Trade Organisation (JETRO). 2014. Japanese Trade and Investment Statistics. https://www.jetro.go.jp/en/reports/statistics/ 
Johnsen, Ingveld. 2015. Gifts Favour the Giver: Norway, Status and the Nobel Peace Prize. In Small State Status Seeking: Norway's Quest for International Standing, ed. Iver B. Neumann and Benjamin de Carvalho. London and New York: Routledge.

Kanwal, Gurmeet. 2010. A Strategic Perspective on India-Myanmar Relations. In Myanmar/ Burma Inside Challenges, Outside Interests, ed. Lex Rieffel. Washington, DC: Brookings Institution Press.

Kemlu. 2015. Indonesia Congratulates Myanmar for the Official Result of Myanmar Election. Indonesian Ministry of Foreign Affairs. November 24, 2015. Accessed March 27, 2017. http://www.kemlu.go.id/en/berita/Pages/ Indonesia-Congratulates-Myanmar-for-the-Official-Result-of-MyanmarElection.aspx

Kompas. 2009. Crucial, The Direct Trade Indonesia-Myanmar [Penting, Perdagangan Langsung Indonesia-Myanmar]. Kompas.com, July 6. Accessed March 27, 2017. http://bisniskeuangan.kompas.com/read/2009/03/17/05300219/Penting. Perdagangan.Langsung.Indonesia-Myanmar.

Lanteigne. 2014. Red and Blue: China's Evolving United Nations Peacekeeping Policies and Soft Power Development. In Asia-Pacific Nations in International Peace Support and Stability Missions, ed. Chiyuki Aoi and Yee-Kuang Heng, 113-140. New York: Palgrave Macmillan.

Lee, Susan and Mi Ki Kyaw Myint. 2015. Myanmar Election Commission Visits Indonesia. In Asia, May 20. http://asiafoundation.org/in-asia/2015/05/20/ myanmar-election-commission-visits-indonesia/

Legêne, Josine, and Flemming Ytzen. 2014. International Actors. In Burma/ Myanmar: Where Now? ed. Mikael Gravers and Flemming Ytzen. Copenhagen: NIAS Press.

Li, Mingjiang. 2008. China Debates Soft Power. Chinese Journal of International Politics 2(June): 287-308.

Lintner, Bertil. 2015. Same Game, Different Tactics. The Irrawaddy, July 2015.

Lun, Min Mang. 2015. Govt. Agrees to More International Witnesses. Myanmar Times, August 7. http://www.mmtimes.com/index.php/national-news/ 15879-govt-agrees-to-more-international-witnesses.html

Macan-Markar, Marwaan. 2013. Indonesia's Special Relationship with Burma Faces Testing Times. The Irrawaddy, April 9. Available at https://www. irrawaddy.com/news/asia/indonesias-special-relationship-with-burmafacestesting-times.html

Martina, Michael and David Brunnstrom. 2015. China's Xi Says to Commit 8,000 Troops for UN Peacekeeping Force. Reuters, September 28. http://www. reuters.com/article/2015/09/29/us-un-assembly-china-idUSKCN0RSIZ1 20150929\#6ybGmIOcqkEcIvel.99

McGregor, Fiona. 2015. Norway Donates to Rakhine State, Denies Financial Interests. Accessed July 6. http://www.mmtimes.com/index.php/nationalnews/15357-norway-donates-to-rakhine-state-denies-financial-interests.html 
McLaughlin, Timothy and Hnin Yadana Zaw. 2015. Under Pressure from China, Kokang Rebels Declare Myanmar Ceasefire. Reuters, June 11. http://www. reuters.com/article/2015/06/11/us-myanmar-rebels-ceasefire-idUSK BN0OR0T120150611

Meng, Jie. 2015. China Supports Myanmar's Peace Process from Start to Finish: Negotiator. Xinhua, October 15. http://news.xinhuanet.com/english/201510/15/c_134717144.htm

Meyer, Eric. 2015. With Oil and Gas Pipelines, China Takes a Shortcut Through Myanmar. Forbes, February 10. http://www.forbes.com/sites/ericrmeyer/2015/02/09/oil-and-gas-china-takes-a-shortcut/

Ministry of Foreign Affairs. 2015. Indonesia, in Cooperation with Myanmar and UK, Shares Experience on the Strengthening of Law Enforcement Personnel, Press Release. Jakarta, June 4, 2015. Accessed March 27, 2017. http://www. kemlu.go.id/id/berita/siaran-pers/Pages/Joint-Press-Release-Indonesia-incooperation-with-Myanmarand-UK-Shares-Experience-on-the-Strengthen.aspx

Myint, Thin. 2013. Why Suu Kyi Absent from ASEAN? The Irrawaddy, January 30. http://www.irrawaddy.org/commentary/across_irrawaddy/why-is-suukyi-absent-from-asean.html

Myint-U. 2011. Where China Meets India: Burma and the New Crossroads of Asia. London: Faber and Faber.

NLD. 2015. National League for Democracy: 2015 Election Manifesto [Authorised Translation]. December 2, 2015. Accessed March 27, 2017. https://drive. google.com/file/d/0B-Tuf9DZaVm9ZmFLdm9wUjhlTzA/view

Otto, Ben. 2014. Indonesia to Continue Push into Myanmar: Widodo. Accessed November 12. http://blogs.wsj.com/indonesiarealtime/2014/11/12/ indonesia-to-continue-push-into-into-myanmar-widodo/

Parameswaran, Prashanth. 2015. China's Influence in Myanmar Facing Growing Scrutiny. The Diplomat, January 7. http://thediplomat.com/2015/01/ chinas-influence-in-myanmar-facing-growing-scrutiny/

PRC State Council. 2011. China's Peaceful Development. Information Office of PRC State Council.

Renshaw, Catherine Shanahan. 2013. Democratic Transformation and Regional Institutions: The Case of Myanmar and ASEAN. Journal of Current Southeast Asian Affairs 1: 29-54.

Richardson, Courtney J. 2011. A Responsible Power? China and the UN Peacekeeping Regime. In China's Evolving Approach to Peacekeeping, ed. Marc Lanteigne and Miwa Hirono. New York and London: Routledge.

Sánchez-Cacicedo, Amaia. 2014. Building States, Building Peace: Global and Regional Involvement in Sri Lanka and Myanmar. Houndmills, UK and New York: Palgrave.

Santosa, Novan Iman. 2012. Myanmar Asks RI to Help Settle Rohingya Problem. The Jakarta Post, November 21. http://www.thejakartapost.com/news/ 2012/11/21/myanmar-asks-ri-help-settle-rohingya-problem.html 
Shin, Aung. 2009. Indonesia Donates to Nargis Victims. Myanmar Times, September 7. http://www.mmtimes.com/index.php/national-news/6111indonesia-donates-to-nargis-victims.html

Sipahutar, Tassia. 2014. BNI to Open New Myanmar Office in November. The Jakarta Post, September 13. http://www.thejakartapost.com/news/2014/ 09/13/bni-open-new-myanmar-office-november.html

Slodkowski, Antoni and Aung Hla Tun. 2015. Myanmar Bans Parties from Criticising Army in State Media. Reuters, August 29.

Song, Junying. 2015. China-ASEAN Relations: Managed Disputes and Sustained Cooperation. In CIIS Blue Book on International Situation and China's Foreign Affairs. Beijing: China Institute of International Studies, World Affairs Press.

Steinberg. 2013. Burma/Myanmar: What Everyone Needs to Know. 2nd ed. Oxford and New York: Oxford University Press.

Storey, Ian. 2009. Emerging Fault Lines in Sino-Burmese Relations: The Kokang Incident. China Brief 9 (18): 5-8. http://www.jamestown.org/single/?tx_ ttnews\%5Btt_news\%5D=35468\#.Vea5q-vZHds

Sun, Yun. 2015. China and Myanmar: Moving Beyond Mutual Dependence. In Myanmar: The Dynamics of an Evolving Polity, ed. David I. Steinberg. Boulder and London: Lynne Rienner.

Suu Kyi, Aung San. 1991. Aung San Suu Kyi-Nobel Lecture. As delivered on acceptance of the Nobel Peace Prize in Oslo. Accessed July 2017. https:// www.nobelprize.org/nobel_prizes/peace/laureates/1991/kyi-lecture_en. html

Suu Kyi, Aung San. 2010. Freedom from Fear. London: Penguin Books.

Taufiqurrahman, M. 2012. Kalla Pledges Aid to Myanmar Rohingya. The Jakarta Post, September 10. http://reliefweb.int/report/indonesia/kalla-pledgesaid-myanmar-rohingya

Telenor. 2017. Telenor Myanmar. Accessed March 27, 2017. https://www.telenor.com.mm/pages/telenormyanmar/147

Telkom. 2013. Telkom Won Tender for Maynmar's International Network [Telkom Berhasil Memenangkan Tender Jaringan Internasional Myanmar]. July 28, 2013. Accessed March 27, 2017. http://www.telkom.co.id/en/ telkom-berhasil-memenangkan-tender-jaringan-internasional-myanmar.html

Tempo. 2014. Myanmar Shows Interest in Buying Indonesia's Defense Products. Tempo. Accessed March 27, 2017. http://nasional.tempo.co/read/ news/2014/09/13/055606685/myanmar-shows-interest-in-buyingindonesiasdefense-products

The Guardian. 2015. Indonesia and Malaysia Agree to Offer 7,000 Migrants Temporary Shelter. May 20, 2015. Accessed March 27, 2017. http://www.theguardian.com/world/2015/may/20/hundreds-more-migrants-rescued-offindonesiaas-pope-calls-for-help 
Wang, Yamei. 2015. Myanmar Ruling Party Leader Highly Appreciates China's Initiative on New Silk Road. Xinhua, April 25. http://news.xinhuanet.com/ english/2015-04/25/c_134183984.htm

Weatherbee, Donald E. 2009. International Relations in Southeast Asia: The Struggle for Autonomy. 2nd ed. Lanham: Rowman \& Littlefield.

Wee, Sui-Lee. 2015. Myanmar Official Accuses China of Interfering in Peace Talks. Reuters, October 8. http://www.reuters.com/article/2015/10/08/ us-myanmar-china-idUSKCNOS22VT20151008\#2v8VxIJLaJQIeWEd.97

Winarti, Agnes. 2013. Myanmar, RI Reaffirm to $\$ 1 \mathrm{~b}$ in Trade. The Jakarta Post, June 13. http://www.thejakartapost.com/news/2013/06/13/myanmar-rireaffirm-lb-trade.html

Wirajuda, Hassan. 2005. Indonesian Foreign Policy: Strategy and Objectives. In DUTA: Indonesia and the World, 24, Cited from Rizal Sukma, Indonesia Finds A New Voice. Journal of Democracy 22 4(Oct. 2011): 117.

- 2014. Myanmar Steps from the Shadows. Strategic Review, OctoberNovember. http://www.sr-indonesia.com/in_the_journal/view/myanmarsteps-from-the-shadows? $\mathrm{pg}=$ all

Wuthnow, Joel. 2008. The Concept of Soft Power in China's Strategic Discourse. Issues and Studies 44(2, June): 1-28.

Xinhua. 2013. Indonesia's Electricity Firm Plans to help Myanmar Cut Electricity Losses. Xinhua. March 27, 2013. Accessed March 27, 2017, http://www. globaltimes.cn/content/771091.shtml

Yan, Xuetong. 2006a. The Rise of China and Its Power Status. Chinese Journal of International Politics 1: 5-33.

- 2006b. Zhongguo ruan shili youdai tígao yanxuetong [Chinese Soft Power Needs to be Improved]. Centre for China in the World Economy. www. ccwe.org.cn/ccweold/journal/2/l.pdf

Yoshihara, Toshi, and James R. Holmes. 2011. Can China Defend a "Core Interest" in the South China Sea? Washington Quarterly 34(2): 45-59.

Yue, Ricky Wai-Kay. 2014. Sino-Myanmar Relations: Is Pauk-Phaw Pragmatic or Rhetoric? Journal of Comparative Asian Development 13(2): 264-289.

Zaw, Win Than. 2012. Indonesia Trade to Hit $\$ 500$ Million by 2015. Myanmar Times, January 9. Available at http://www.mmtimes.com/index.php/ business/1291-indonesia-trade-to-hit-500-million-by-2015.html

\section{INTERVIEWS}

Interviews with Chinese government officials, Yangon, April 2015. Interview with senior Indian Embassy official, Yangon, August 2015. Interviews with Japanese Embassy officials, Yangon, August 2015. Interview with senior Switzerland Embassy official, Yangon, August 2015. Interview with Chief Military Training, Myanmar Armed Forces, August 2015. 
Interview with Agus Widjojo, August 12, 2015.

Interview with Hassan Wirajuda, August 11, 2015.

Interview with MoFA, Directorate of East Asian and Pacific Affairs, August 10, 2015. Interview with some lecturers in Department of International Relations from Yangon University, August 2015.

Interview with Habibie Center, August 2015.

Interviews with administators at the University of Yangon, Yangon, August 2015. Interviews with education officials and lecturers, University of Yangon, August 2015. Interviews with Norwegian Embassy officials, Yangon, August 2015.

Lina A. Alexandra is Senior Researcher, Centre for Strategic and International Studies (CSIS), Jakarta.

Marc Lanteigne is Senior Lecturer, Centre for Defence and Security Studies, Massey University, Auckland, New Zealand.

Open Access This chapter is licensed under the terms of the Creative Commons Attribution 4.0 International License (http://creativecommons.org/licenses/ by $/ 4.0 /)$, which permits use, sharing, adaptation, distribution and reproduction in any medium or format, as long as you give appropriate credit to the original author(s) and the source, provide a link to the Creative Commons license and indicate if changes were made.

The images or other third party material in this chapter are included in the chapter's Creative Commons license, unless indicated otherwise in a credit line to the material. If material is not included in the chapter's Creative Commons license and your intended use is not permitted by statutory regulation or exceeds the permitted use, you will need to obtain permission directly from the copyright holder.

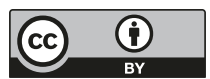

